ARTICLE

\title{
Fast microwave heating-based one-step synthesis of DNA and RNA modified gold nanoparticles
}

Mengqi Huang ${ }^{1,4}$, Erhu Xiong ${ }^{1,4,5 凶}$, Yan Wang ${ }^{2}$, Menglu Hu${ }^{1}$, Huahua Yue ${ }^{1}$, Tian Tian 1 , Debin Zhu ${ }^{3}$, Hong Liu² \& Xiaoming Zhou (1) $1,5 \bowtie$

DNA/RNA-gold nanoparticle (DNA/RNA-AuNP) nanoprobes have been widely employed for nanobiotechnology applications. Here, we discover that both thiolated and non-thiolated DNA/RNA can be efficiently attached to AuNPs to achieve high-stable spherical nucleic acid (SNA) within minutes under a domestic microwave (MW)-assisted heating-dry circumstance. Further studies show that for non-thiolated DNA/RNA the conjugation is poly (T/U) tag dependent. Spectroscopy, test strip hybridization, and loading counting experiments indicate that low-affinity poly ( $T / U)$ tag mediates the formation of a standing-up conformation, which is distributed in the outer layer of SNA structure. In further application studies, CRISPR/Cas9-sgRNA (136 bp), SARS-CoV-2 RNA fragment (1278 bp), and rolling circle amplification (RCA) DNA products (over $1000 \mathrm{bp}$ ) can be successfully attached on AuNPs, which overcomes the routine methods in long-chain nucleic acid-AuNP conjugation, exhibiting great promise in biosensing and nucleic acids delivery applications. Current heating-dry strategy has improved traditional DNA/RNA-AuNP conjugation methods in simplicity, rapidity, cost, and universality.

\footnotetext{
${ }^{1}$ School of Life Sciences, South China Normal University, 510631 Guangzhou, China. ${ }^{2}$ Key Laboratory of Theoretical Chemistry of Environment Ministry of Education, School of Chemistry, South China Normal University, 510006 Guangzhou, China. ${ }^{3}$ Guangzhou Key Laboratory of Analytical Chemistry for Biomedicine, School of Chemistry, South China Normal University, 510006 Guangzhou, China. ${ }^{4}$ These authors contributed equally: Mengai Huang, Erhu Xiong.

${ }^{5}$ These authors jointly supervised this work: Erhu Xiong, Xiaoming Zhou. 凶email: xiongeh2019@m.scnu.edu.cn; zhouxm@scnu.edu.cn
} 
T he invention of gold nanoparticles (AuNPs)-based spherical nucleic acids (SNAs), such as DNA-AuNP and RNAAuNP conjugates, has attracted worldwide interest and opened up the field of nanobiotechnology ${ }^{1-4}$. This unique nanomaterial consists of AuNPs core and a dense nucleic acid, allowing molecular recognition and programmability of DNA/ RNA to be combined with unique optical, chemical, electrical, and catalytic properties of AuNPs, thus, impart SNA chemphysical properties and biological functions $s^{5,6}$. Numerous applications have since been made including programmed DNA/RNA nanotechnology, molecular diagnosis, imaging, gene regulation, and drug delivery ${ }^{6-16}$.

The construction of DNA-AuNP and RNA-AuNP conjugates is critical for these successful applications in biology, chemistry, medicine, and nanoscience. Conventionally, to attach negatively charged DNA and RNA to negatively charged AuNPs, a key is to screen the charge repulsion between AuNPs and nucleic acids. The most commonly used method is salt-aging method ${ }^{17-19}$, where salt was gradually added into the mixture of thiol (SH)- or poly (A)-tagged DNA and AuNPs to reduce charge repulsion. However, the salt-aging method required over two days to completion, making it a highly time-consuming process. A few new labeling methods were developed by adding $\operatorname{acids}^{20,21}$, surfactants ${ }^{22}$, polymers ${ }^{23,24}$, and organic solvent ${ }^{25}$, however, the use of extra reagents complicates the labeling process and may reduce the applicability of SNAs. Recently developed freeze-thaw method could attach thiol-modified oligonucleotides on AuNPs in a time-effective and reagentless form ${ }^{26}$. However, DNA/RNA thiolation increases the cost, especially for long oligonucleotides, whose chemical modification is very expensive and difficult ${ }^{27,28}$. Our group have successfully used a freeze-thaw method to attach thiol-free DNA/RNA on AuNPs, but this method still lacks universality due to sequence structure effect ${ }^{29}$. In summary, it seems that there is still a lack of an ideal DNA-AuNP and RNAAuNP construction method that can simultaneously satisfy the simplicity, rapidity, low cost, and versatility. In particular, almost all currently reported DNA-AuNP and RNA-AuNP construction methods only demonstrated their feasibility for functionalization of short DNA and RNA sequences. Long DNA/RNA-conjugated AuNPs nanostructures, which may be developed as potential new biosensing, DNA/RNA vaccine ${ }^{30,31}$, and gene editing tool delivery strategies ${ }^{32,33}$, have been rarely developed.

Here, we report a microwave (MW)-assisted heating-dry method to construct SNAs, where a domestic microwave oven is used as a heater to drive the labeling process to completion in minutes without the need for extra reagents, and demonstrated its applicability to both thiolated and non-thiolated DNA/RNA. Further, for attaching non-thiolated DNA/RNA, we find that DNA/RNAAuNP conjugates are poly $(\mathrm{T} / \mathrm{U})$ tag dependent under heating-dry circumstance. Spectroscopy, test strip hybridization, and loading counting experiments indicate that poly $(\mathrm{T} / \mathrm{U})$ tag is distributed in the outer layer of such a SNA structure. It is inferred that this essential low-affinity poly $(\mathrm{T} / \mathrm{U})$ tag is mainly responsible for the formation of a standing-up conformation in the AuNPs surface. Notably, our method addresses the deficiencies of traditional methods in long DNA/RNA labeling and allows selective functionalization of AuNPs with sgRNA (136 bp), RNA (1278 bp) fragment encoding nucleocapsid $(N)$ protein (GU280_gp10 locus, termed $N$ gene) of SARS-CoV-2 (accession: NC_045512.2), and rolling circle amplification (RCA) DNA products (over $1000 \mathrm{bp}$ ). In addition, the potential applications of this labeling strategy are demonstrated by developing new colorimetric identification of DNA single-base mutation or detecting viral DNA based on clustered regularly interspaced short palindromic repeats (CRISPR)based lateral flow strategy. The successful construction of long and structured DNA/RNA-conjugated AuNPs nanostructure may also indicate that a new functional nucleic acids delivery system based on AuNPs as a carrier can be developed. Overall, currently presented labeling strategy represents a fast, simple, cost-effective, and universal method that can be extended to the conjugation of almost all types of DNA and RNA sequences, which will expand the use of SNAs in biomedicine and nanotechnology in the future.

\section{Results and discussion}

Fast construction of DNA-AuNP and RNA-AuNP conjugates based on MW-assisted heating-dry method. Both nucleic acids and AuNPs solutions exhibit negatively charged properties, in order to promote effective nucleic acid-AuNP conjugation, some well-proven strategies, such as salt-aging ${ }^{17,18}$ and low-pH methods $s^{20,21}$, are to shield the charge to benefit the affinity interaction between nucleic acids and AuNPs. Other effective strategies, such as freeze-thaw ${ }^{26}$ and solvent methods ${ }^{25}$, are to increase the local concentration by compressing the physical space, thereby forcing the chemical covalent reaction or physical cross-linking between AuNPs and nucleic acids in an ultralocalized reaction volume. Our previous study has shown that freeze-thaw method encounters the influence of secondary structure of oligonucleotides on AuNPs-based labeling reaction ${ }^{29}$, thus lacks sequence universality for construction of AuNPs-based bioprobes. Here, we invented a new DNA-AuNP and RNAAuNP construction strategy through MW-assisted heating-dry method (Fig. 1a, b). Heating is well known to destroy the higherorder nucleic acid structure and stretch the nucleic acid strands ${ }^{34}$. The microwave oven, which is used in almost every kitchen, is a simple and cost-effective heating device ${ }^{35,36}$. In particular, the microwave radiation can be completely reflected on the metal surface and therefore has no effect on the metal particles, while the aqueous solution can be quickly heated and dried. We envisioned that this heating-dry strategy could be an ideal DNA/ RNA-AuNP labeling method due to its role in simultaneously stretch the nucleic acid structure and concentrate the reaction volume. Accordingly, we firstly mixed SH-DNA with AuNPs solution (Supplementary Fig. 1). Surprisingly, after a few minutes of MW heating and drying, AuNPs showed red clumps, while AuNPs showed purple-black clumps with thiol-free DNA or in the absence of DNA (Supplementary Fig. 1). After addition of salt solution to the resulted red clumps, AuNPs immediately redispersed into a red colloidal state, indicating that AuNPs and SH-DNA may be covalently conjugated (Supplementary Fig. 1). These phenomena signified that a simple DNA-AuNP labeling technique using microwave-assisted heating-dry method has been developed.

We further seek to develop a universal and thiol-free nucleic acid-AuNP construction method (Fig. 1a). Although thiol modification is very easy to obtain for short nucleic acid sequences, for long-chain DNA and RNA, the chemical modification is very expensive and difficult. Therefore, the conjugation of long-chain DNA and RNA to AuNPs is rarely achieved. Adenine (A) base has been well confirmed to have good affinity for $\mathrm{Au}^{37,38}$, and poly (A)-tagged nucleic acid sequences have also been successfully applied to the coupling of AuNPs based on freeze-thaw or salt-aging methods ${ }^{18,29}$. Therefore, we take it for granted that poly (A)-tagged nucleic acid sequences should be suitable for the heating-dry labeling strategy we developed. However, to our surprise, in our attempt we found that only the poly $(\mathrm{T} / \mathrm{U})$-tagged nucleic acids showed a preferred labeling efficiency under heating-dry circumstance (Fig. 1a, b). In the absence of DNA/RNA sequences or in the presence of random DNA/RNA sequences without poly (T/U) tags, AuNPs solutions will aggregate irreversibly (Fig. 1b). Further, results showed that heating-dry strategy can also be applied to labeling 


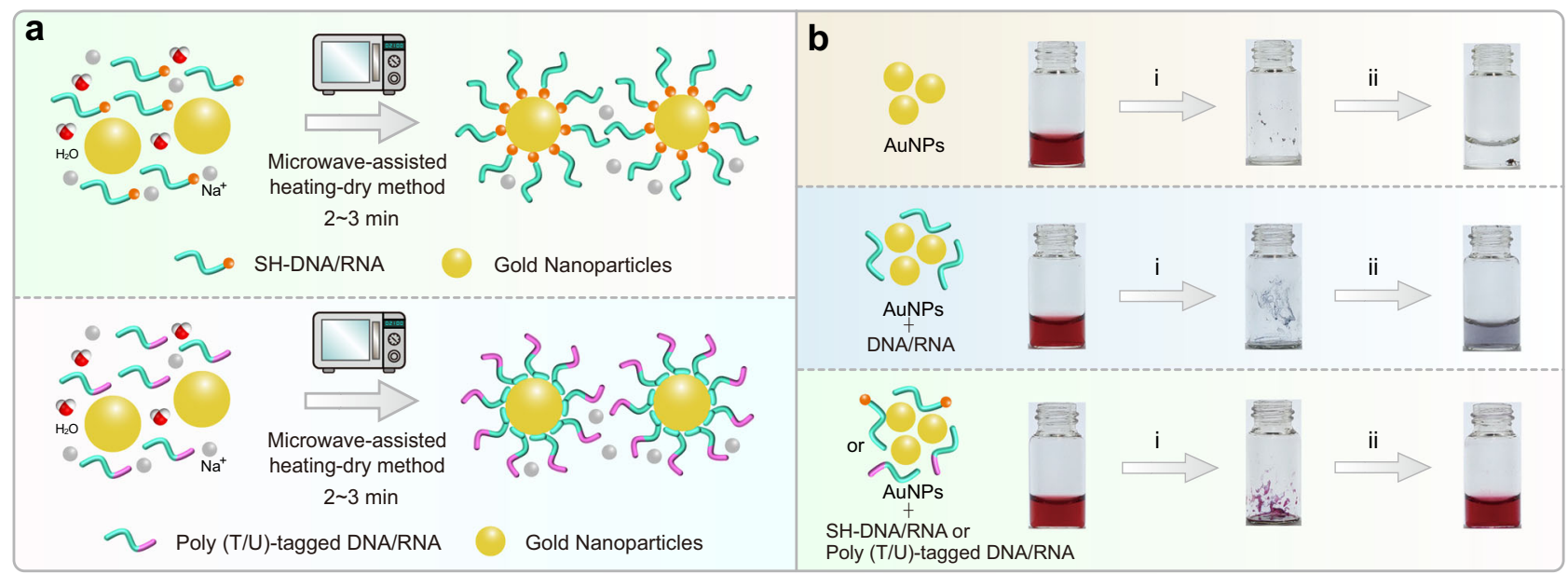

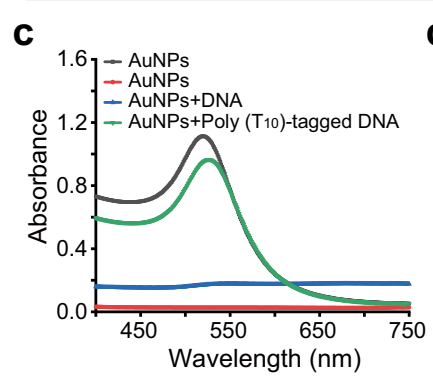

g

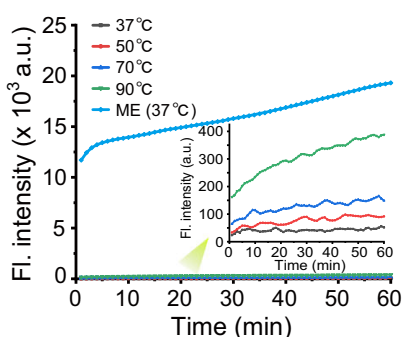

d

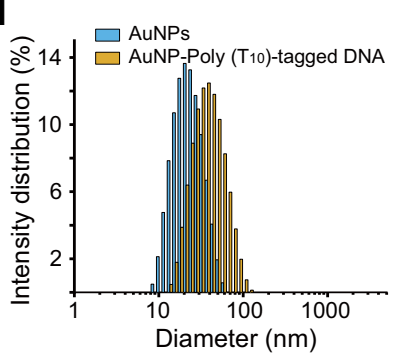

h

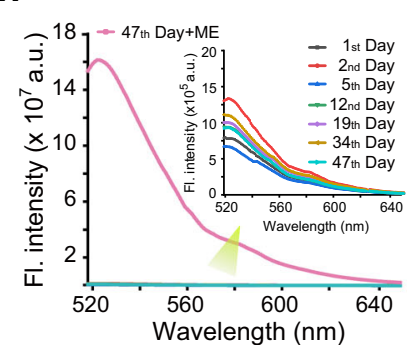

e

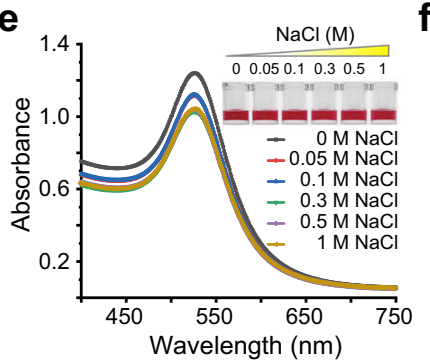

i

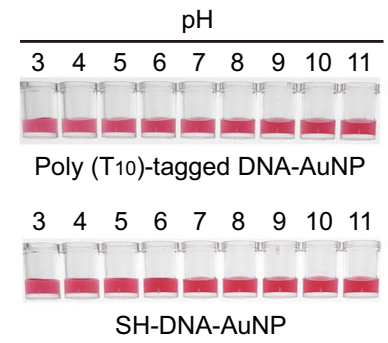

f

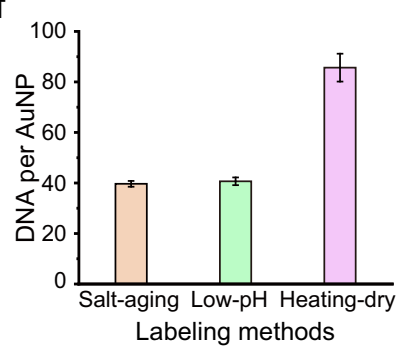

j

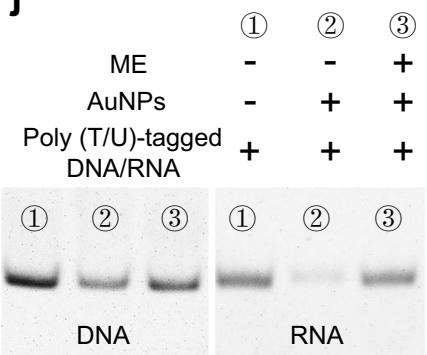

Fig. 1 Fast construction of DNA/RNA-AuNP conjugates based on $\mathbf{M W}$-assisted heating-dry method. a Scheme of attaching thiolated and non-thiolated DNA/RNA to AuNPs using MW-assisted heating-dry method, in which the heating-dry process is driven by a domestic microwave oven for 2-3 min. b Photographs of AuNPs before and after heating-dry process. The bare AuNPs and random DNA/RNA sequence mixed AuNPs aggregated after heating dry treatment. While poly (T/U)-tagged DNA-AuNP retained monodispersed and seems red after heating dry and resuspension. (i) MW-assisted heating dry; (ii) resuspending with water or buffer. c Characterization of the non-thiolated DNA/RNA-AuNPs conjugates based on MW-assisted heating-dry labeling method using UV-vis absorption spectroscopy. d Dynamic light scattering measurement of the hydrodynamic diameters of bare AuNPs and DNAAuNP conjugates. e Photographs and absorption spectroscopy showing the stability evaluation of DNA-AuNP conjugates in different NaCl concentrations. f The measured number of DNA probes attached to each AuNP. The DNA-AuNP conjugates were constructed using poly ( $\mathrm{A}$ )-based salt-aging and low-pH methods, and poly (T)-based MW-assisted heating-dry method, respectively. Error bars = standard deviation $(n=3)$. $\mathbf{g}$ Thermal stability evaluation of DNA-AuNP conjugates. The process of DNA desorption from AuNPs was monitored by measuring the fluorescence intensity of FAM on DNA probes at varied temperatures. a.u. arbitrary units. $\mathbf{h}$ Time stability evaluation of DNA-AuNP conjugates. The process of DNA dissociation from AuNPs was monitored by measuring the fluorescence intensity of FAM on DNA probes at different storage times. a.u. arbitrary units. $\mathbf{i}$ pH stability evaluation of thiolated and non-thiolated DNA-AuNP conjugates. $\mathbf{j}$ Evaluation of the integrality of DNA/RNA strands by 10\% polyacrylamide gel electrophoresis (PAGE). Lane 1, the DNA/RNA strands used for heating-dry labeling. Lane 2, the excessive unlabeled DNA/RNA strands in the supernatant solution after the heating-dry labeling process. Lane 3, the released DNA/RNA strands replaced by ME from the resulted DNA/RNA-AuNP conjugates.

of larger-sized AuNPs and SH-DNA-gold nanorods (AuNRs) conjugation (Supplementary Fig. 2).

In order to further characterize this DNA-AuNP conjugate, we directly measured the UV-vis spectroscopy of the poly (T)-tagged DNA conjugated AuNPs solution. It was shown that the absorption peak of AuNPs with poly (T)-tagged DNA exhibited a $6 \mathrm{~nm}$ red-shift, suggesting that there are DNA attached on the AuNPs surface (Fig. 1c). To further demonstrate the poly (T)-tagged DNA attachment on AuNPs, the AuNPs solution was centrifuged and washed and then analyzed by dynamic light scattering (DLS). The hydrated particle size of DNA-AuNP conjugate is larger than the bare AuNPs (Fig. 1d and Supplementary Table 1), further indicating that poly (T)-tagged DNA strands were attached. In addition, the electron microscope results confirmed that the MW-assisted heating treatment did not damage the morphology of AuNPs (Supplementary Fig. 3).

Next, we wonder whether the DNA-AuNP conjugate is enough stable. Firstly, we tested its stability by resuspending it with different salt concentrations. Results showed that the DNA-AuNP conjugates were still monodispersed even challenge $1 \mathrm{M} \mathrm{NaCl}$ solution and its absorption peak did not show observable shift (Fig. 1e), while the bare AuNPs aggregated at a salt concentration 
of $50 \mathrm{mM}$ (Supplementary Fig. 4). Such high salt stability indicated that there were many poly (T)-tagged DNA sequences attached to the AuNPs surface. We subsequently measured the number of FAM-labeled poly (T)-DNA probes assembled on each AuNP according to a $\beta$-mercaptoethanol (ME)-based displacement experiment (Supplementary Fig. $5 \mathrm{a}-\mathrm{c})^{39}$. As a comparison, the number of FAM-poly (A)-DNA on each AuNP that labeled using two reported thiol-free methods, poly (A)-based salt-aging and low- $\mathrm{pH}$ methods, were also measured. Results showed that the number of poly (T)-tagged DNA probes attach to each AuNP by MW-assisted heating-dry method is 83 , which is about 2 times higher than the salt-aging and low-pH method (Fig. 1f). Further test indicated that when SH-DNA was used, for each AuNP approximately 270 DNA strands can be loaded (Supplementary Fig. 5d). We believe that the high DNA density is not due to the multilayered adsorption caused by hydrogen bonding between DNA strands. This is confirmed in a subsequent thermal stability experiment, where FAM-labeled DNA-AuNP conjugates exhibited negligible fluorescence increase in the solution at different temperatures, indicating high thermal stability of the DNA-AuNP conjugates and non-specific adsorption was also excluded (Fig. 1g). However, a rapid increase in fluorescence intensity was observed when the replacement reagent ME was mixed with the DNA-AuNP conjugates (Fig. 1g). At the same time, we also monitored the time stability based on the measurement of the fluorescence of DNA-AuNP conjugates. The results showed that only negligible fluorescence intensity increases even for up to 47-day storage, indicating that the conjugates are stable for longtime storage (Fig. 1h). Further, the DNA-AuNP conjugates stability at a wide $\mathrm{pH}$ range $(\mathrm{pH} 3 \sim 11)$ was also tested. It was showed that both thiolated and non-thiolated DNA/RNA-AuNP conjugates exhibit excellent $\mathrm{pH}$ tolerance (Fig. 1i).

One may worry about whether such a high-temperature labeling condition will damage DNA and affect subsequent use. We then tested the nucleic acid integrity and hybridization ability of the resulted DNA/RNA-AuNP conjugates. It was found that DNA/RNA is still intact and the conjugates work as well as the conventional SH-DNA-labeled AuNP probes based on a test strip hybridization experiment (Fig. 1j and Supplementary Fig. 6). Additionally, we also evaluated the potential risk of two typical DNA damages, such as pyrimidine dimer and apurinic/ apyrimidinic (AP) sites, and the experimental results indicated that the $\mathrm{MW}$-assisted heating-dry treatment did not generate potential pyrimidine dimers and AP sites on the DNA strands (Supplementary Figs. 7 and 8).

Non-thiolated DNA/RNA-AuNP conjugation is poly (T/U) tag dependent. To further understand the sequence-based labeling effect, we designed four types of DNA with poly $\left(\mathrm{A}_{10}\right)$, poly $\left(\mathrm{T}_{10}\right)$, poly $\left(\mathrm{C}_{10}\right)$, and poly $\left(\mathrm{G}_{10}\right)$ tags at $5^{\prime}$ - and $3^{\prime}$-terminal and mixed them with AuNPs, respectively. Moreover, four RNAs with poly $\left(\mathrm{rA}_{10}\right)$, poly $\left(\mathrm{rU}_{10}\right)$, poly $\left(\mathrm{rC}_{10}\right)$, and poly $\left(\mathrm{rG}_{10}\right)$ tag at $3^{\prime}$-terminal were also applied. After heating-dry and centrifugation-washing treatment, the DNA/RNA-AuNP conjugates were resuspended in $1 \mathrm{M} \mathrm{NaCl}$ solution. Results showed that only AuNPs with poly (T/U)-tagged DNA/RNA retained red color in $1 \mathrm{M} \mathrm{NaCl}$ solution, indicating AuNPs were protected by high-density DNA strands (Fig. 2a(i), (ii), (iv)). Further assay showed that poly (A/T/C/G) tags at the middle position exhibited the similar phenomena (Fig. 2a(iii)). Labeling using DNA sequences with poly (A/T/C/G) tags with varied lengths have also been tested. Under all situations only these poly (T)-tagged DNAs are efficient, thus the poly (A/ $\mathrm{C} / \mathrm{G}$ ) tags length effect is excluded (Fig. $2 \mathrm{~b}$ and Supplementary Fig. 9). The results also showed that five $\mathrm{T}$ bases appeared to be enough for efficient labeling when the $\mathrm{T}$ bases are located at $5^{\prime}$ - and $3^{\prime}$-terminal, and $>10 \mathrm{~T}$ bases did not significantly improve the labeling efficiency (Fig. 2b). For T base located at the middle region of the DNA sequence, the labeling efficiency increased with the increase of $\mathrm{T}$ base number and $\mathrm{T}_{30}$ base showed the highest labeling efficiency (Fig. 2b). All these observations indicated that poly (T) tag is essential for successful labeling and this labeling method exhibits flexibility in the position and length of poly (T) tag. In addition to the DNA sequence with terminal and middle tags, we also proved that the MW-assisted heating-dry method can achieve successful labeling for DNA sequence with poly $(\mathrm{T})$ tag located at both ends or hairpin DNA sequence with shielded poly $(\mathrm{T})$ tag in the stem region (Supplementary Fig. 10a, b). The results indicated that heating-dry method can be applied to structured nucleic acid labeling, thus providing a more generic way than previously reported techniques, such as freeze-thaw method (Supplementary Fig. 10c).

To more detailly evaluate the role of $\mathrm{T}$ base in labeling process, we replaced one or two $T$ bases with $A, C$, or $G$ base in poly $\left(T_{5}\right)$ -tagged DNA sequences. Results showed that in most case the labeling efficiency dramatically decreased or totally lost upon this replacement (Fig. 2c), which indicated that five consecutive $\mathrm{T}$ bases are very critical. We also noticed that when replacing single $\mathrm{T}$ with $\mathrm{G}$ the labeling efficiency did not dramatically decreased. Previous observations and our colorimetric experiments indicated that $\mathrm{T}$ base has the lowest Au affinity (Supplementary Fig. 11). Some pioneering works have concluded that the Au affinity order for all four bases is: $A>C>G>T^{40-42}$. Dependence of lowaffinity $\mathrm{T}$ base during the heating-dry process prompted us to know how it is involved in this labeling method. To simplify the base effect evaluation, we designed four types of sequences consisting of two kinds of bases to observe this labeling response. Interestingly, we found that the $\mathrm{T}_{10} \mathrm{~A}_{1}$ sequence was effectively conjugated, while $\mathrm{T}_{10} \mathrm{~T}_{1}, \mathrm{~T}_{10} \mathrm{C}_{1}$, and $\mathrm{T}_{10} \mathrm{G}_{1}$ did not (Fig. 2d). Further experiments showed that $\mathrm{T}_{10} \mathrm{~A}_{2}, \mathrm{~T}_{10} \mathrm{C}_{2}$, and $\mathrm{T}_{10} \mathrm{G}_{2}$ can also be effectively conjugated while $\mathrm{T}_{10} \mathrm{~T}_{2}$ does not (Fig. $2 \mathrm{~d}$ ). However, when $A_{10}, C_{10}$ and $G_{10}$ were used as the tag, all labeling reactions were unsuccessful (Fig. $2 \mathrm{~d}$ ). These experiments implied that $\mathrm{T}$ base is essential in the heating-dry labeling strategy but it is not directly involved in the DNA-AuNP conjugation.

Experimental observation of poly $(\mathrm{T})$ tag orientation. In order to clarify the underlying labeling mechanism, we firstly used surface-enhanced Raman spectroscopy (SERS) to observe the poly (T) tag orientation in the SNA structure. Because the labeling mechanism based on Au-SH conjugates is well proved, we then tested the SERS signal based on the hybridization of a $5^{\prime}-\mathrm{SH}$ DNA-AuNP conjugates and a complementary DNA (cDNA) probe with ROX labeled at $5^{\prime}$ - and $3^{\prime}$-terminal, respectively. When $3^{\prime}$-ROX-cDNA-5 $5^{\prime}$ and $3^{\prime}$-cDNA-ROX-5' hybridized with the $5^{\prime}$-SH-DNA-AuNP conjugates, respectively, ROX will be close to or away from AuNPs surface. Expectantly, we observed significant SERS signal enhancement after $3^{\prime}$-ROX-cDNA-5' probe hybridization (Fig. 3a(i)). This indicated that SERS is suitable for observing the poly $(\mathrm{T})$ tag orientation. Accordingly, we designed an "amphiphilic" DNA sequence with $\mathrm{A}_{5}$ and $\mathrm{T}_{5}$ tags located at $5^{\prime}$ - and $3^{\prime}$ - terminals, respectively, for AuNP conjugation. $3^{\prime}$ ROX-cDNA- $5^{\prime}$ and $3^{\prime}$-cDNA-ROX-5' probes were used for observing the SERS signals after hybridization. Experiments showed that $3^{\prime}$-ROX-cDNA-5' probe mediated significant SERS signal enhancement (Fig. 3a(ii)). When replaced the $\mathrm{T}_{5}$ tag with $\mathrm{T}_{10}$ tag, more significant SERS signal was observed (Fig. 3a(iii)). These results supported that poly $(\mathrm{T})$ tag is distributed in the outer layers of SNA structures.

We further executed a structured DNA labeling experiment to elucidate labeling mechanism. Two kinds of DNA sequences with 


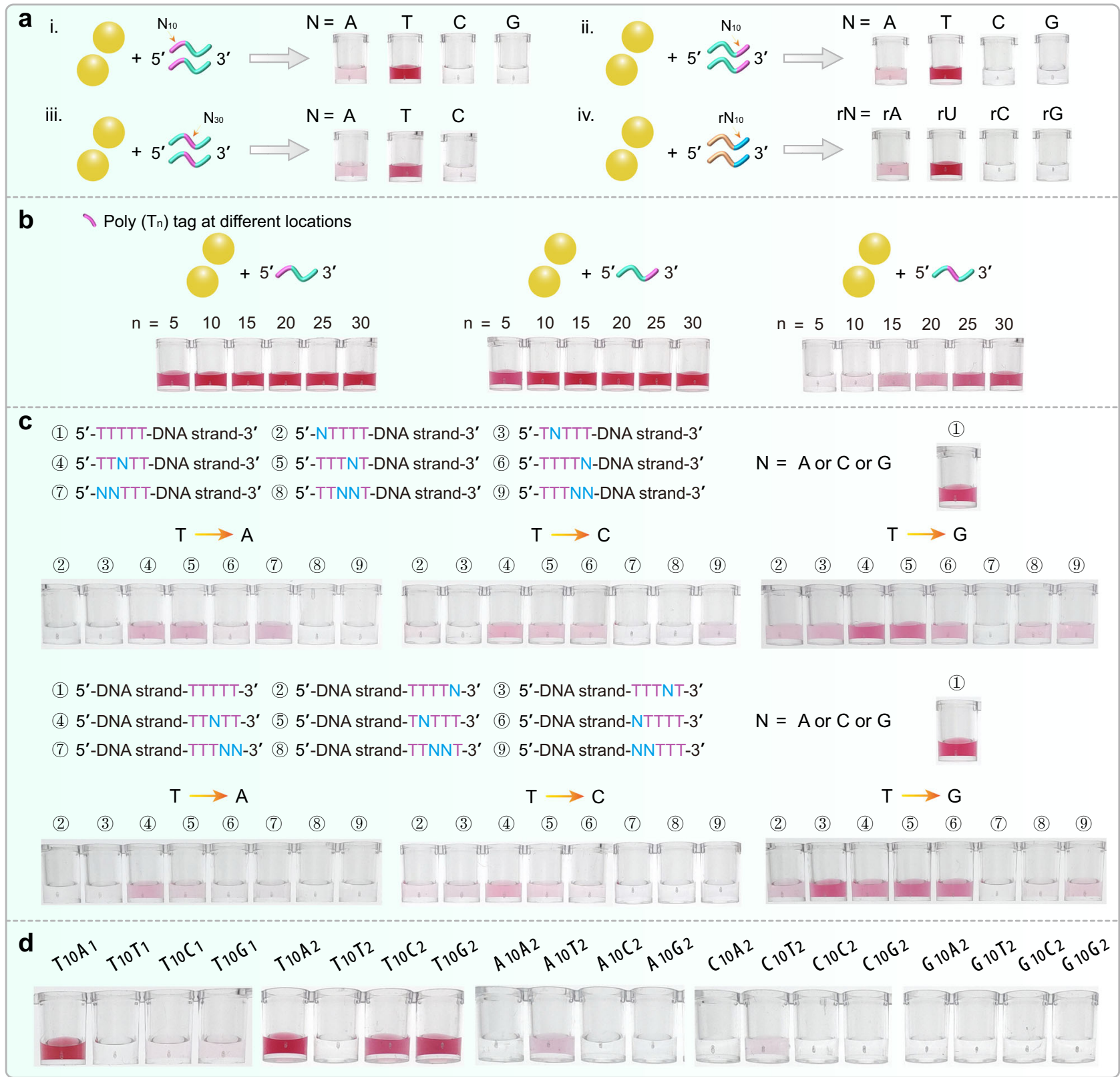

Fig. 2 Poly (T/U) tag-dependent DNA/RNA-AuNP conjugates. a MW-assisted heating-dry labeling of DNA-AuNP and RNA-AuNP conjugates. Photographs showing the labeling results of DNA sequences with poly ( $T$ ) tag at $5^{\prime}$-terminal (i), 3'-terminal (ii), and in the middle region (iii). Photographs showing the labeling results of RNA sequence with poly ( $\mathrm{rU}$ ) tag at $5^{\prime}$-terminal (iv). An inefficient and failed labeling will lead to the AuNPs aggregation. b Photographs showing the labeling results of poly (T)-tagged DNA with different numbers of T base located at $5^{\prime}$-terminal, $3^{\prime}$-terminal and in the middle region. c Photographs showing the labeling results of poly $\left(T_{5}\right)$-tagged DNA, in which one or two $T$ bases in $T_{5}$ were replaced by $A$, $C$, and $G$ base. Poly ( $T$ ) tags at both $5^{\prime}$ - and $3^{\prime}$-terminal are evaluated. d Observation of the poly $\left(\mathrm{T}_{10}\right)$ dependence and role in the heating-dry labeling process.

well-confirmed G-quadruplex (G4) structures (G4-DNA1 and G4-DNA2) are employed. The circular dichroism (CD) spectroscopy was used to measure these two G4-contained sequences and random sequence, and the results showed G4-DNA1 and G4DNA2 contained sequences present characteristic peaks at around 240 and $260 \mathrm{~nm}$ while random DNA sequence presents characteristic peaks at around 250 and $280 \mathrm{~nm}$ (Fig. 3b(i), c(i)). Subsequently, we designed G4-DNA1 with $\mathrm{T}_{10}$ tag at $5^{\prime}$-terminal and G4-DNA2 with $\mathrm{T}_{10}$ tag at both $5^{\prime}$ - and $3^{\prime}$-terminal for the AuNP conjugation. According to this design, it can be expected that if $\mathrm{T}_{10}$ is involved in the AuNP conjugation, the G4 sequence will expose to the outer layer so that its structure is retained. Conversely, if the G4 sequence is involved in the AuNP conjugation, the G4 structure will be destroyed. CD spectra showed that G4 characteristic peaks disappeared after AuNP conjugation, verifying that G4 sequence is involved in the AuNP conjugation (Fig. 3b(ii), c(ii)). Further, we replaced the $T_{10}$ tag at 3'-terminal with $A_{5}, A_{10}$, and $A_{15}$ tags, respectively. It is expected that high-affinity poly (A) tag will preferentially bind to the AuNPs surface, so the G4 sequence will be released to maintain its intact structure. CD spectra of these resulted DNA-AuNP conjugates are tested, which showed that G4 characteristic peaks are restored (Fig. 3b(iii), c(iii)).

In order to strengthen the understanding of labeling mechanism, and also supply guide for future applications, we employed test strip hybridization assay to evaluate the hybridization 


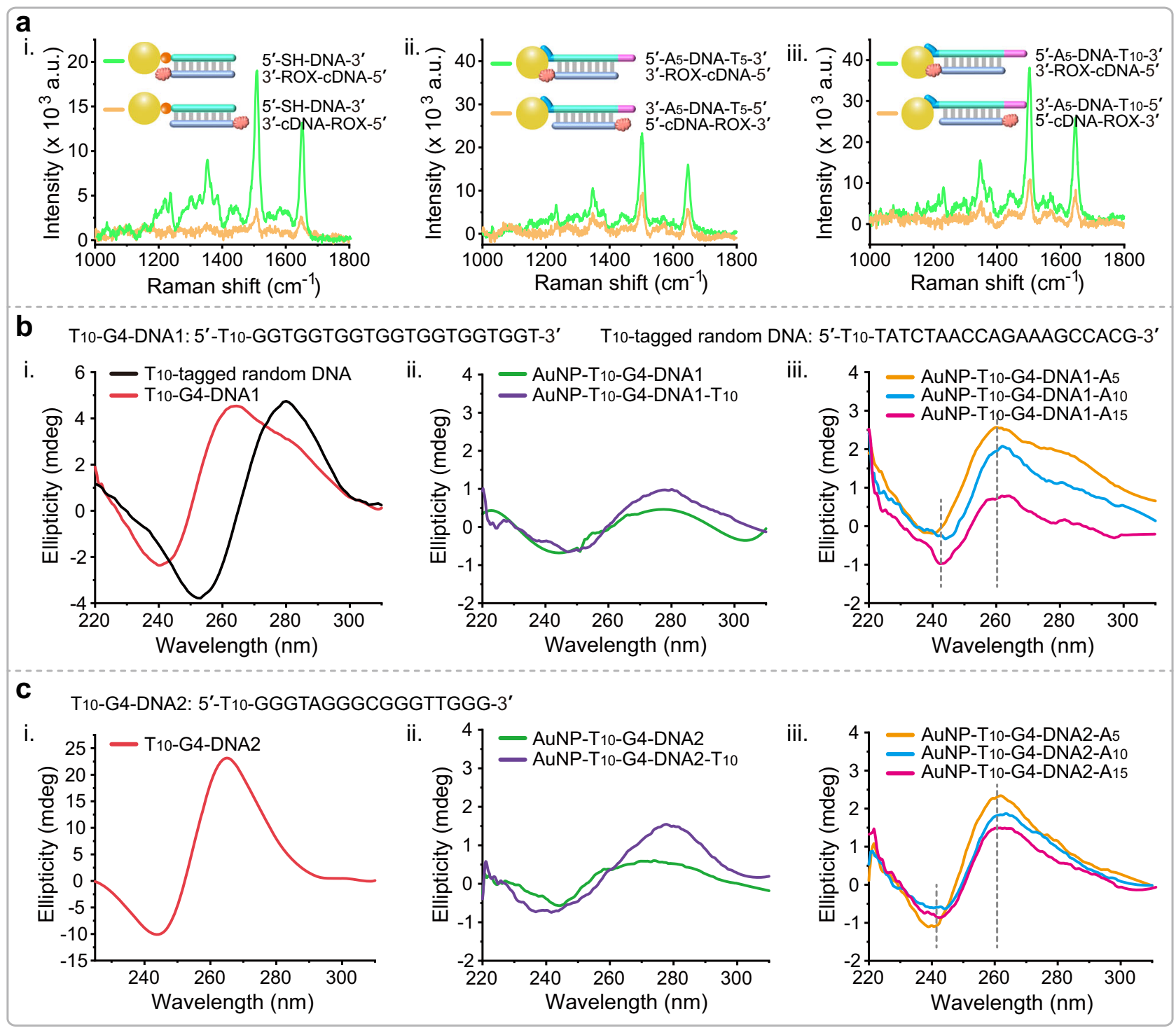

Fig. 3 Spectroscopic observation of poly (T) tag orientation in the SNA structure. a (i) SERS experiments showing the Raman signal variation when cDNAs labeled with ROX at 5'- and 3'-terminal hybridized with the SH-DNA-AuNP conjugates, respectively. (ii) SERS experiments showing the Raman signals variation when cDNA labeled with ROX at $3^{\prime}$-terminal hybridized with the $A_{5}-D N A-T_{5}$ and $T_{5}-D N A-A_{5}$ conjugated AuNP probes, respectively. (iii) SERS experiments showing the Raman signal variation when cDNA labeled with ROX at 3'-terminal hybridized with the $A_{5}-D N A-T_{10}$ and $T_{10}-D N A-A_{5}$ conjugated AuNP probes, respectively. For all SERS experiments, $30 \mathrm{~nm}$ diameter AuNPs are used. a.u. arbitrary units. $\mathbf{b}$ (i) CD spectra of the $\mathrm{T}_{10}$-tagged G4-DNA1 sequence and T10-tagged random DNA sequence. G4-DNA1 sequence has two characteristic peaks at around 240 and $260 \mathrm{~nm}$. Random DNA sequence has two characteristic peaks at around 250 and $280 \mathrm{~nm}$. (ii) CD spectra of AuNP-T10-G4-DNA1 and AuNP-T $10-G 4-D N A 1-T_{10}$ Conjugates. (iii) CD spectra of AuNP-T $10-$ G4-DNA1-A, AuNP-T $10-G 4-D N A 1-A_{10}$, and AuNP-T $10-G 4-D N A 1-A_{15}$ conjugates. c (i) CD spectra T10-tagged G4-DNA2 sequence. (ii) CD spectra of AuNP-T $10-G 4-D N A 2$ and AuNP-T $10-G 4-D N A 2-T_{10}$ conjugates. (iii) CD spectra of AuNP-T $10-G 4-D N A 2-A_{5}$, AuNP-T $10-G 4-D N A 2-A_{10}$, and AuNP-T $10-$ G4-DNA2- $A_{15}$ conjugates. mdeg millidegree.

properties of the resulted DNA-AuNP conjugates. DNA sequences with varied poly ( $\mathrm{T}$ ) tag lengths were designed for AuNP conjugation and a cDNA can hybridize with these DNA sequences was pre-coated on the test strip. It was found that with the increase of poly (T) tag length, the hybridization efficiency decreased, whether $13 \mathrm{~nm}$ or $30 \mathrm{~nm}$ AuNP bioprobes (Fig. 4a(i)). These results indicated that increasing the poly (T) length leads to an increase in steric hindrance and a decrease in hybridization efficiency. Subsequently, the same DNA sequences were tagged with a fixed poly $\left(\mathrm{T}_{7}\right)$ at $5^{\prime}$-terminal and varied poly $(\mathrm{A})$ lengths at $3^{\prime}$-terminal. The resulted DNA-AuNP conjugates were applied to the test strip hybridization and presented almost equal hybridization efficiency when increasing the poly (A) length from $A_{2}$ to $A_{15}$ (Fig. $4 a(i i)$ ). It was also noticed that further increase of poly
(A) length to 25 has a reverse effect on hybridization (Fig. 4a(ii)). It is possible that the longer poly (A) tag leads to a decrease in the number of probes conjugated to the AuNPs surface, thus affecting the hybridization. At last, we pre-coated a poly $\left(\mathrm{A}_{7}\right)$ probe on the test strip to test the above-mentioned DNA-AuNP conjugates. Robust and equal hybridization efficiency can be observed for DNA-AuNP conjugates with varied poly (A) lengths (Fig. 4a(ii)). These experiments provide strong evidence that poly $(\mathrm{T})$ is not involved in conjugation with AuNPs and is distributed in the outer layer of the SNA structure. This can also be further corroborated by measuring the attached DNA numbers at three kinds of labeling situations, where Poly $\left(\mathrm{T}_{\mathrm{n}}\right)$-Poly $\left(\mathrm{C}_{5}\right)$-FAM, Poly $\left(\mathrm{T}_{10}\right)$-Poly $\left(\mathrm{C}_{\mathrm{n}}\right)$-FAM, and Poly $\left(\mathrm{T}_{10}\right)$-Poly $\left(\mathrm{C}_{5}\right)$-FAM were used for labeling (Supplementary Figs. 12-14). Attached DNA 


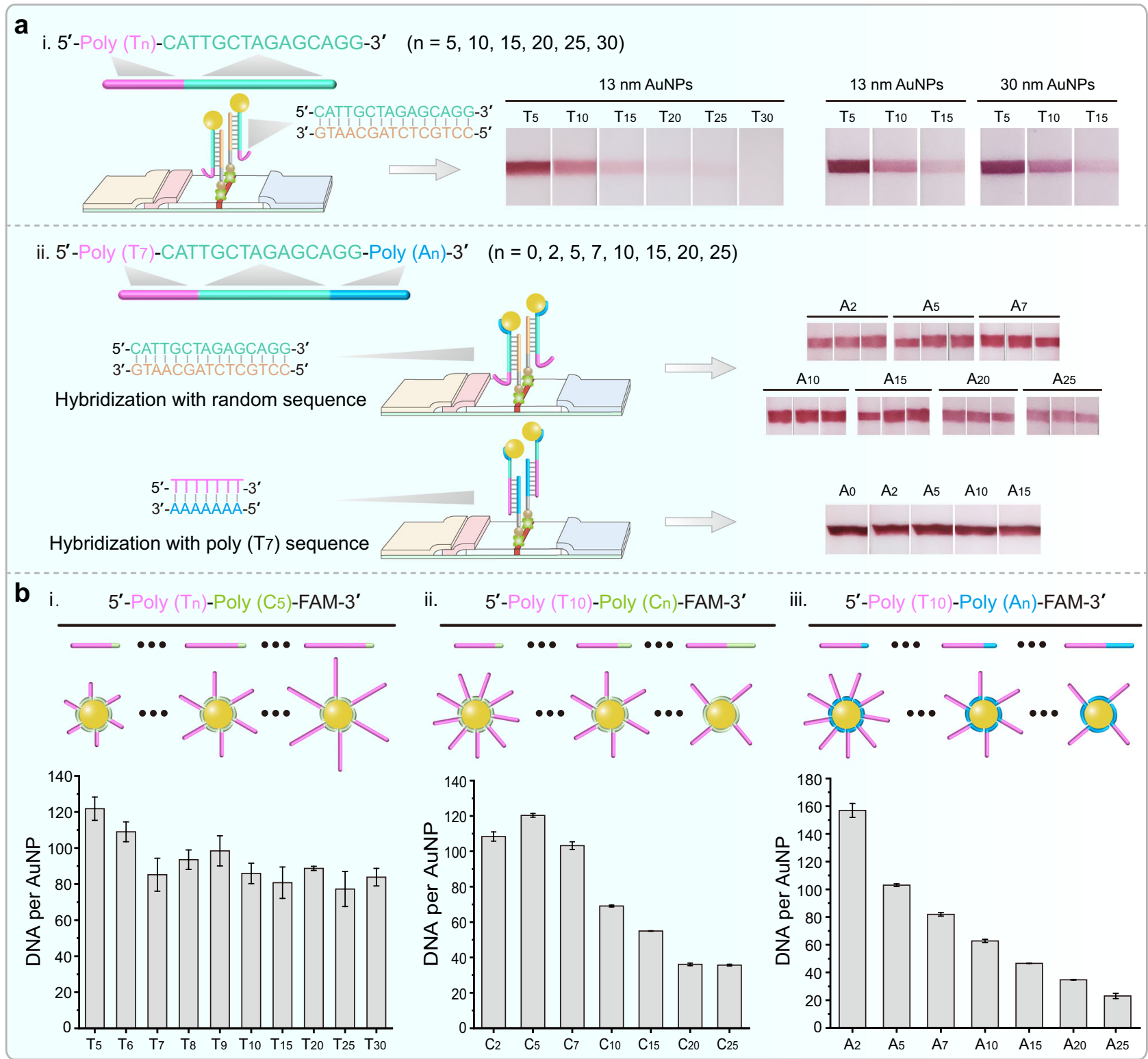

Fig. 4 Verification of poly (T) tag orientation in the SNA structure using test trip hybridization and loading counting experiments. a (i) Scheme showing the poly $\left(T_{n}\right)$-tagged DNA probes are used for AuNPs labeling and the lateral flow hybridization device. A complementary DNA probe is precoated on the lateral flow device used for hybridization. 13 and $30 \mathrm{~nm}$ diameter AuNPs are used for labeling and subsequent hybridization experiments. (ii) DNA sequences with poly $\left(T_{7}\right)$ and poly $\left(A_{n}\right)$ tags at both terminals are used for AuNPs labeling and subsequent hybridization experiments. Two kinds of DNA probes are pre-coated on the lateral flow device for hybridizing with $T_{7}$ and random DNA region, respectively. Hybridization results are observed by the naked eyes. $\mathbf{b}$ Counting of the attached DNA number from three labeling situations. Three kinds of DNA probes including (i) Poly $\left(T_{n}\right)-P o l y\left(C_{5}\right)$, (ii) Poly $\left(T_{10}\right)$-Poly $\left(C_{n}\right)$, and (iii) Poly $\left(T_{10}\right)$-Poly $\left(C_{5}\right)$, are used for labeling. FAM dye is modified at $3^{\prime}$-terminal of these DNA sequences. Error bars $=$ standard deviation $(n=3)$.

is almost unchanged with varied low-affinity poly (T) lengths but maintains fixed high-affinity poly $\left(\mathrm{C}_{5}\right)$ tag (Fig. $4 \mathrm{~b}(\mathrm{i})$ ). Keep the poly $\left(\mathrm{T}_{10}\right)$ tag fixed, while increasing the length of poly (C) and poly (A) tags, attached DNA is gradually reduced (Fig. 4b(ii), (iii)).

Mechanism description. It is fascinating that poly (T/U)-tagged DNA/RNA can be loaded on the AuNPs surface at high density by simply heating-dry treatment. Previous study has shown that heating could drive DNA to be adsorbed onto AuNPs or graphene $e^{43,44}$. To understand whether this labeling is only induced by heating, some random DNA sequences with poly $\left(\mathrm{A}_{10} / \mathrm{T}_{10} / \mathrm{C}_{10} / \mathrm{G}_{10}\right)$ tags at $5^{\prime}$-terminal were mixed with AuNPs under heating (Fig. 5a and Supplementary Fig. 15). As observed, under both 90 and $150^{\circ} \mathrm{C}$, the AuNPs aggregated after the centrifugation-resuspension treatment, which show that heating process cannot mediate efficient DNA-AuNP conjugation (Fig. 5a, top panel and Supplementary Fig. 15). Conversely, all poly (T)-tagged DNA sequences could be efficiently attached to AuNPs using heating-dry method (Fig. 5a, below panel). In another test, when AuNPs solution were mixed with six kinds of DNAs and dried at lower temperatures $\left(30\right.$ and $90{ }^{\circ} \mathrm{C}$ ), feasible labeling was achieved although with nonuniform labeling efficiency (Supplementary Fig. 15). The nonuniform labeling efficiency may be due to the structural influence of some DNA sequences, which in turn affects the stability, density, and activity 

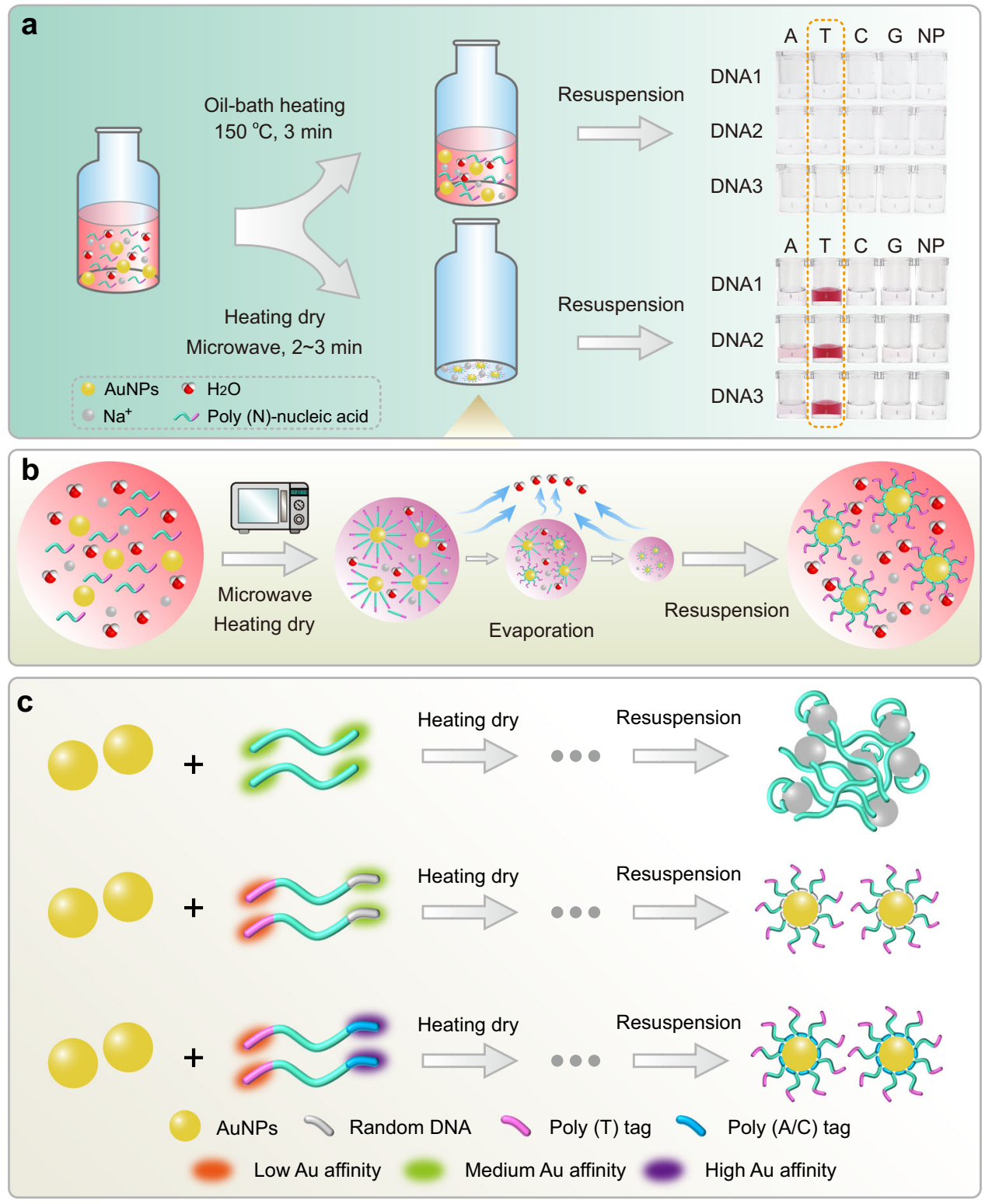

Fig. 5 Mechanism description on DNA-AuNP conjugation by the $\mathbf{M W}$-assisted heating-dry method. a Photographs showing a failed labeling with solely heating at $150^{\circ} \mathrm{C}$ for $3 \mathrm{~min}$, while there was a successful labeling of poly ( $\mathrm{T}$ )-tagged DNA with heating-dry method. Poly (A/C/G)-tagged DNA and nonpoly base (NP) DNA probes exhibited failed labeling. An inefficient and failed labeling will lead to the AuNPs aggregation. $\mathbf{b}$ MW-assisted heating-dry method involves two consecutive processes: (i) MW-assisted heating induced high temperature unwinds the coiled structure of oligonucleotides. (ii) MWassisted water evaporation concentrates the DNA/RNA, AuNPs and salt, thereby accelerating the attachment of DNA/RNA on the AuNPs surface. c DNA sequences without poly $(T)$ tag present medium Au affinity at both terminals. Under heating-dry conditions, DNA adsorbed on the AuNPs surface disorderly. Inadequate DNA adsorption or DNA-mediated crosslink adsorption will cause the AuNPs aggregation. Benefiting from the low Au affinity of poly $(T)$ tag, poly $(T)$-tagged DNA exhibits an "amphiphilic"-like characteristic. Therefore, the sequence at one end (either a random sequence with medium Au affinity or poly (A/C) sequence with high Au affinity) mediates the DNA-AuNP conjugation, and the poly ( $T$ )-contained sequence at the other end is distributed in the outer layer of SNA structure.

of the adsorbed DNA strands. Conversely, high and uniform labeling efficiency can be achieved only when both drying and heating conditions are available (Supplementary Fig. 15). It is well known that heat can destroy the higher-level structure of nucleic acid strand, thereby stretching them into an uncoiled state. Therefore, in the present work, we tried to use heating to stretch the nucleic acid strands, which can make them to be well bound with AuNPs surface, especially the long-chain/structural nucleic acid strands. In addition, the MW-assisted heating condition can promote the rapid water evaporation in the solution of AuNPs and nucleic acid strands to reach a drying state, which compresses their physical space and increases their local concentrations to achieve rapid labeling, thereby greatly improving the labeling efficiency and density.

Further, we found that poly $\left(\mathrm{T}_{10}\right)$-tagged DNA at the concentration of $1.25 \mu \mathrm{M}$ is enough for heating-dry labeling (Supplementary Fig. 16a). Based on the data of DNA loading per AuNP (83 poly $\left(\mathrm{T}_{10}\right)$-tagged DNA strands each AuNP) and the measured AuNPs concentration after labeling completion, we were surprised that $>80 \%$ of the DNA strands were utilized in the labeling process. Such a high DNA utilization ratio should be ascribed to the concentration effect under the heating-dry 
condition. For SH-DNA, a critical DNA concentration of $5 \mu \mathrm{M}$ is required for successful conjugation (Supplementary Fig. 16b), which is consistent with the results of about 270 SH-DNA strands attached for each AuNP (Supplementary Fig. 3d). These observations indicated that both evaporation-mediated DNA condensing and heating-mediated DNA stretch cooperatively promote the high-density DNA loading on AuNPs surface (Fig. 5b).

Based on the above observations and poly $(\mathrm{T})$ tag orientation experiments, we concluded that the heating-dry method presents the following mechanism: (i) for random DNA/RNA sequence, both $5^{\prime}$ - and $3^{\prime}$-terminal or middle region have medium and undifferentiated $\mathrm{Au}$ affinity. Under rapid heating-dry condition, flat and cross-linked DNA-AuNP adsorption behavior is dominant. The resulted DNA-AuNP complex is thus unstable against heating and high salt concentration due to the low DNA adsorption density (Fig. 5c); (ii) poly (T/U)-tagged DNA/RNA exhibits an "amphiphilic"-like characteristic, where poly (T/U) tag has low Au affinity and the other end has medium Au affinity (random base composition) or high Au affinity (A/C-rich nucleic acid sequences). Under rapid heating-dry condition, nucleic acid sequences are clustered and medium- and high-affinity regions are preferentially bound to AuNPs, thus the low-affinity poly (T/ $\mathrm{U})$-contained region is distributed in the outer layer due to the repulsion effect. Such a "standing-up" conformation allows highdensity nucleic acid strands attached thus mediating the formation of high-stable SNA structure (Fig. 5c). It is important to point out that for efficient conjugation the low-affinity tag is essential from all our observations, which is consistent with the previous report ${ }^{45}$. In a test, labeling failure occurred when the $\mathrm{Au}$ affinity of poly (T) was enhanced by phosphorothioate (PS) modification. However, addition of modification-free poly $(\mathrm{T})$ tag at the other end, the successful conjugation was restored (Supplementary Fig. 17). In addition, to investigate the relationship between the nucleic acid strand length and the number of $\mathrm{T}$ bases for successful adsorption, we performed molecular dynamics simulation and binding free energy calculation and the results showed that with the same affinity sequence, the poly $\left(\mathrm{T}_{10}\right)$-DNA strands is more inclined to be adsorbed on the AuNPs surface than that of poly $\left(\mathrm{T}_{5}\right)$-DNA strands, and more $\mathrm{T}$ bases may provide higher driving force to attach on the AuNPs surface (Supplementary Fig. 18), which can also be seen by naked-eye observation of these two labeling results (Fig. 2b).

\footnotetext{
MW-assisted heating-dry method enables colorimetric detection of poly (T)-interspaced RCA products. After establishing a fast, low-cost and facile DNA-AuNP construction method, we wondered whether this method could be used for long-stranded DNA-AuNP conjugation. RCA, an isothermal amplification reaction, is performed using circular DNA template and DNA primer to produce long single-stranded DNA (ssDNA) which contains many tandem repeating sequences complementary to circular DNA template ${ }^{46}$. Here, we designed a padlock probe containing a $\mathrm{A}_{40}$ sequence at non-recognition region and a 20-bp sequence for specific target DNA recognition. After performing ligation and RCA reaction, the resulting long ssDNA products will contain interspaced tandem repeated $\mathrm{T}_{40}$ sequence, which is potential suitable for AuNP-based labeling using heating-dry method (Fig. 6a). The gel analysis showed that the length of RCA products is over $1000 \mathrm{bp}$ (Fig. $6 \mathrm{~b}$ ). With MW-assisted heating-dry method, we observed that the poly (T)-interspaced RCA products could be effectively attached thus AuNPs presented in a red monodispersed solution, while AuNPs aggregated when mixed with RCA products with random repeated sequence (Fig. 6c), which indicated a selective AuNPs-based attachment with $\mathrm{T}_{40}$
}

sequence in RCA products. Based on this observation, we further developed a simple colorimetric single-base mutation diagnostic platform. As shown in Fig. 6d, the padlock probe will be ligated in the present of perfectly matched target sequence thus the RCA reaction could generate long ssDNA strands containing $\mathrm{T}_{40}$ sequence, while no ligation and RCA amplification occur with single-base mismatched sequence (Fig. 6e). Subsequently, heating-dry method was utilized to colorimetric detection of the RCA products. The solution retained red when the sample with perfectly matched target, while it was colorless when the sample with single-base mismatched sequence or without target due to AuNPs aggregation (Fig. 6f). These results indicated that our developed diagnostic platform based on padlock-dependent ligation, RCA reaction, and MW-assisted heating-dry method enables a new colorimetric gene mutation detection of DNA sequence.

MW-assisted heating-dry method enables construction of long and structured ssRNA-AuNP nanostructure. Conjugation of long and structured RNA on AuNPs is of significance due to a wide range of potential applications in biomedicine and nanobiotechnology 47,48 , which, however, remains a challenge. This is because chemical thiol-modification of long-chain RNA is very expensive and difficult ${ }^{25,26}$. Currently, high-fidelity chemical synthesis of RNA with more than 200 bases is almost impossible to achieve. Here, we challenged to conjugate AuNPs with long and structured RNA using the heating-dry method. To demonstrate this possibility, poly (U)-tagged sgRNA (136 bp) and $N$ gene RNA (N-RNA, $1278 \mathrm{bp}$ ) of SARS-CoV-2 were obtained using in vitro T7 transcription based on a poly (A)-tagged DNA template (Fig. 6g). The sequence, structure, and labeling details of sgRNA and N-RNA are shown in Fig. $6 \mathrm{~h}$, i, respectively. sgRNA is a guide RNA in Cas9 gene editing tool and $N$ gene RNA is an important functional gene of SARS-CoV-2. Conjugation of these RNAs to AuNPs may give birth to new medical applications, such as nucleic acid drugs and vaccines ${ }^{30,31}$, delivery of gene editor tool $^{32,33}$, due to the excellent cell entry capabilities of AuNPs ${ }^{12,49}$.

As shown in Fig. 6j, after mixture of RNA and AuNPs and a few minutes of heating-dry process, both the absorption spectra and photographs indicated that poly (U)-tagged sgRNA and N-RNA can be successfully functionalized on AuNPs, while it fails to efficiently load sgRNA and N-RNA without poly (U) tag. The measured hydrodynamic diameters of sgRNA-AuNP and NRNA-AuNP conjugates are about 141 and $255 \mathrm{~nm}$ (Fig. 6k and Supplementary Table 1), respectively, revealing larger RNA strands attached. Next, RNAs were displaced from the AuNPs surface by ME and were subjected to the gel electrophoresis, showing the same map when compared to the original in vitro T7 RNA transcription products (Fig. 6l), indicating that RNA sequence was not damaged during the heating-dry process.

Finally, we demonstrated an application of the resulted RNAAuNP conjugates by developing a CRISPR/Cas9-based nucleic acid test strip using sgRNA-conjugated AuNPs. Previously, we have developed a test strip strategy by employing Cas9/sgRNA as the recognition element to specifically recognize double-stranded DNA (dsDNA), which is superior to the traditional test strip in terms of simplicity, specificity, and portability ${ }^{50,51}$. This conventional Cas9/sgRNA-based test strip employed a DNA-AuNP probe to hybridize with the loop region of sgRNA for lateral flow detection of virus and pathogenic bacteria. Benefiting from the new developed RNA-AuNP conjugation method, now we can further simplify the previous test strip procedure by direct construction of the Cas9/sgRNA-AuNP probes. We next tested if the resulted Cas9/sgRNA-AuNP probes still possess the recognition and cleavage ability. Results showed that both of Cas9/ 

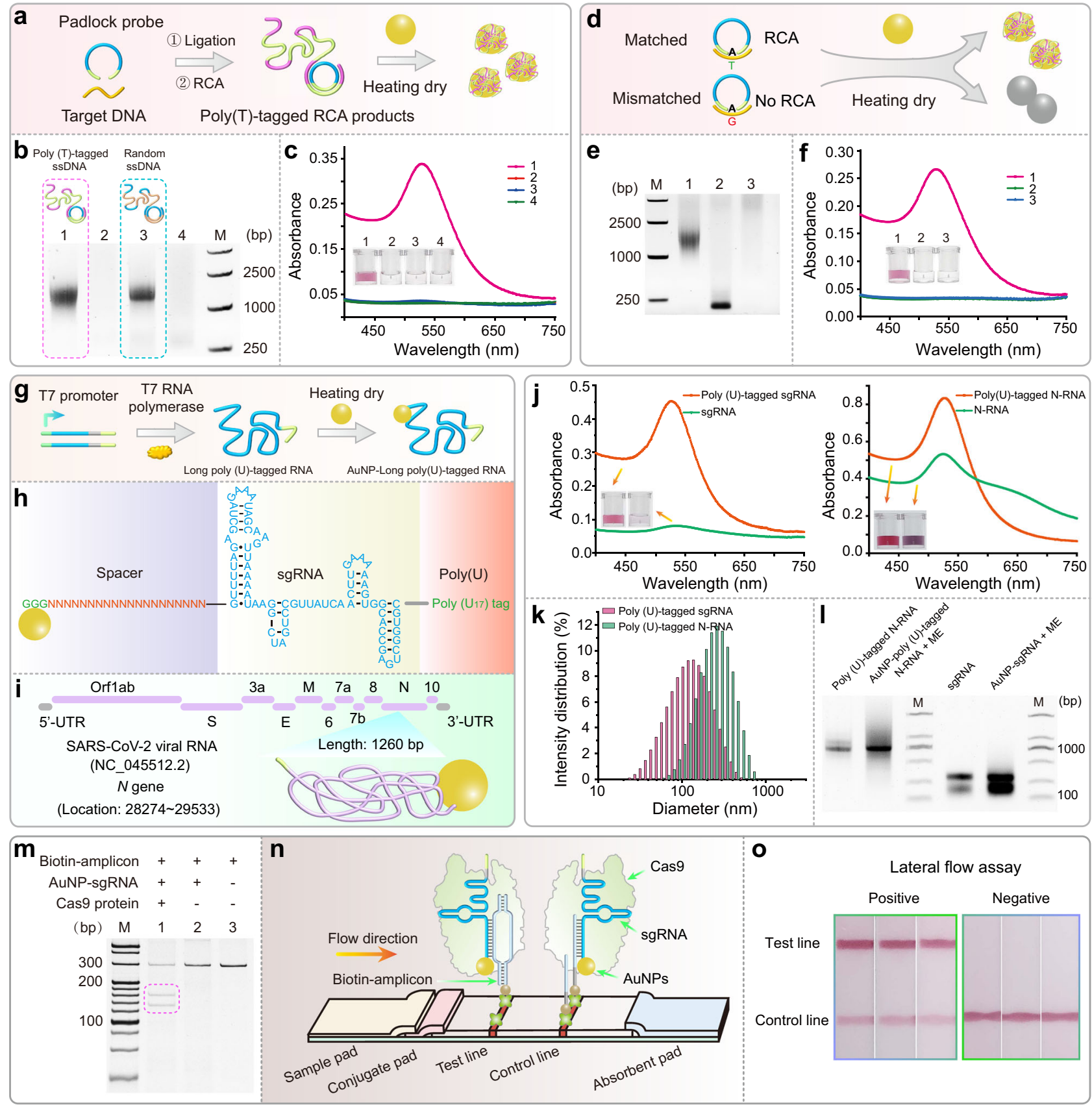

Fig. 6 MW-assisted heating-dry method enables labeling of long DNA and long-structured RNA and the application on biosensing. a MW-assisted heating-dry method for labeling RCA products containing interspaced poly $(T)$ tag. $\mathbf{b}$ Gel electrophoresis analysis of RCA products. Lanes 1 and 3 represent the poly (T)-contained ssDNA and random ssDNA from RCA reaction. Lanes 2 and 4 are the control samples without target DNA template. $\mathbf{c}$ Photographs and the corresponding absorption spectroscopy data showing the labeling results of RCA products. $\mathbf{d}$ Development of colorimetric single-base mutation diagnosis based on ligation-dependent RCA reaction and MW-assisted heating-dry method. e Gel electrophoresis analysis of RCA products with perfectly matched or single-base mismatched target DNA. Mismatched target DNA will lead to failed ligation and RCA reaction. Lane 1 represents the RCA products with matched DNA, lane 2 represents the RCA reaction products with single-base mismatched DNA, lane 3 represents the control sample without target DNA. f Photographs and the corresponding absorption spectroscopy data showing the detection results. $\mathbf{g}$ Labeling of long-structured RNA with poly (U)tagged sgRNA (136 bp) and long N-RNA (1278 bp) was obtained using in vitro T7 transcription. The sequence, structure, and labeling details of sgRNA and N-RNA are shown in $\mathbf{h}$ and $\mathbf{i}$, respectively. $\mathbf{j}$ Characteristic of labeling results of sgRNA and N-RNA using absorption spectroscopy. $\mathbf{k}$ Dynamic light scattering measurement of the AuNP-sgRNA and AuNP-N-RNA conjugates. I Gel electrophoresis analysis of the in vitro transcribed sgRNA and N-RNA, and sgRNA and N-RNA displaced from AuNPs surface by ME. $\mathbf{m}$ Electrophoresis analysis of the cleavage ability of the assembled Cas9/sgRNA-AuNP complex. $\mathbf{n}$ Development of CRISPR/Cas9-mediated test strip assay. Schematic illustration of the test strip based on the Cas9/sgRNA-AuNP probes. Cas9/sgRNA-AuNPs probes recognize the biotinylated DNA products and flow through the test strip. The resulting complexes of Cas9/sgRNA-AuNP probe and biotinylated DNA are retained by streptavidin on the test line. Excess Cas9/sgRNA-AuNP probes flow through the control line and are captured by the precoated ssDNA capture probes. o Photographs taken from Cas9-sgRNA-AuNP probes-based test strip assay for detection of B646L (VP72) gene from ASFV. 
sgRNA and Cas9/sgRNA-AuNP probes could maintain the DNA recognition and cleavage ability (Fig. $6 \mathrm{~m}, \mathrm{n}$ and Supplementary Fig. 19a). It has now been widely accepted that the binding free energy of bases to the AuNPs surface is greater than the pairing between bases ${ }^{38}$. Thus, it is confusing how specific parts of longer DNA/RNA are able to recognize and hybridize to other structures if the entire sequence has some affinity for the AuNPs. We therefore hypothesized that these SNA structures must contain some recognition sequences that exhibit fully erect and free conformational characteristics. The SNA obtained by MWassisted heating-drying method may follow the site-specific adsorption mechanism: during the initial water evaporation process, nucleic acid strands may be randomly attached to the AuNPs surface. Most of the sites on the AuNPs may be occupied by such random adsorption strands, but there are still some narrow gaps. As the water is completely evaporated, the concentration of nucleic acid strands on the surface of the AuNPs increases dramatically, resulting in saturated adsorption. It can be inferred that only a few bases at the end of the nucleic acid strands may be able to participate in saturation adsorption, so that the resulting SNA contains some nucleic acid strands that exhibit fully erect and free conformational characteristics. These free-conformation nucleic acid strands are easily used for biorecognition reaction (Supplementary Fig. 20).

To demonstrate the detection application of this Cas9/sgRNAAuNP probe, we amplified the B646L gene encoding the viral protein 72 (VP72) of African swine fever virus (ASFV, accession: MN715134.1) with biotinylated primers and designed the corresponding Cas9/sgRNA-AuNP probe to recognize the B646L (VP72) gene amplicons (Supplementary Fig. 19b). Subsequent test strip results showed that the positive sample presents a band with high intensity at test line, while the negative sample does not (Fig. 6o), indicating the successful application of the novel Cas9/sgRNA-AuNPs test strip.

In summary, we invented a fast, general, and cost-effective method to functionalize AuNPs with DNA and RNA using a MW-assisted heating-dry method. The whole labeling process could be completed in minutes due to the rapid water evaporation by only employing a domestic microwave oven (Supplementary Movie). Rapid water evaporation by MW-assisted heating-dry treatment is a convenient and environmentally friendly way to force AuNPs to bind nucleic acid strands efficiently. Because both AuNPs and nucleic acid strands are negatively charged, previously, the binding of AuNPs to nucleic acid strands was regulated by adjusting $\mathrm{pH}^{20,21}$, adding salts ${ }^{17,18}$, or organic solvents ${ }^{25}$. Compared to these state-of-the-art labeling methods, MW-assisted heating-dry method exhibits maximum labeling efficiency, excellent sequence generality, and can produce the most stable DNA-AuNP conjugates, representing a new and advantageous construction method for AuNP conjugates (Supplementary Fig. 21). In addition to its confirmed hybridization performance, AuNP-based bioprobes obtained from MW-assisted heating-dry method also exhibit promising new application potential, such as colorimetric DNA single-base mutation analysis and virus DNA detection. Moreover, the heating-dry method can stretch any nucleic acid strand with a complex secondary structure, making the labeling process unaffected by structureresulted affinity sequence shielding, thus this method is universal to almost any sequence. We have successfully demonstrated its ability for attaching the long-chain and structured nucleic acids on AuNPs surface, which is difficult to achieve by routine methods. Therefore, it may stimulate academic interest in branching out into some relatively unexplored areas based on the applications of long-chain DNA/RNA-AuNP conjugates, such as the delivery of gene editing tools, RNA vaccine, and other functional DNA/RNAs.

\section{Methods}

Preparation of $13 \mathbf{~ n m ~ A u N P s . ~ T h e ~} 13 \mathrm{~nm}$ AuNPs were synthesized using citrate reduction method as previously reported ${ }^{52,53}$. In brief, $100 \mathrm{~mL}$ of $1 \mathrm{mM} \mathrm{HAuCl}$ solution (catalog number: 484385) was added into glass flask and heated to boiling. Then quickly stirred $\mathrm{HAuCl}_{4}$ solution and added $10 \mathrm{~mL}$ of $38.8 \mathrm{mM}$ sodium citrate solution. Keep the above solution boiling and stirred for 15-20 min, finally cooled to room temperature with stirring. The prepared AuNPs were stored at $4{ }^{\circ} \mathrm{C}$ in the dark.

Preparation of $\mathbf{3 0} \mathbf{~ n m}$ and $\mathbf{4 0} \mathbf{~ n m ~ A u N P s . ~ T h e ~} 30 \mathrm{~nm}$ and $40 \mathrm{~nm}$ AuNPs were synthesized using citrate reduction method as previously reported ${ }^{54}$. In brief, $100 \mathrm{~mL}$ of $1 \mathrm{mM} \mathrm{HAuCl}_{4}$ solution was added into glass flask and heated to boiling. Then quickly stirred $\mathrm{HAuCl}_{4}$ solution and added $6 \mathrm{~mL}(5 \mathrm{~mL})$ of $38.8 \mathrm{mM}$ sodium citrate solution for $30 \mathrm{~nm}(40 \mathrm{~nm})$ AuNPs preparation. Keep the above solution boiling and stirred for 15-20 min, finally cooled to room temperature with stirring. The prepared AuNPs were stored at $4{ }^{\circ} \mathrm{C}$ in the dark.

Preparation of AuNRs. The AuNRs were synthesized as previously reported ${ }^{55}$ Firstly, $220 \mu \mathrm{L}$ of $50 \mathrm{mM} \mathrm{HAuCl}_{4}$ solution was added to $10 \mathrm{~mL}$ of $0.2 \mathrm{M}$ cetyltrimethylammonium bromide (CTAB, catalog number: C-3960-53) solution, followed by a slight vortex mixing. When the floccule completely dissolved, $21 \mu \mathrm{L}$ of $0.1 \mathrm{M} \mathrm{AgNO}_{3}$ (catalog number: 204390 ) solution and $212 \mu \mathrm{L}$ of $0.1 \mathrm{M}$ ascorbic acid were added to the mixture, followed by a slight vortex mixing. Subsequently, $2.5 \mu \mathrm{L}$ of $1 \mathrm{mM} \mathrm{NaBH}_{4}$ was added to above mixture and incubated at room temperature for $12 \mathrm{~h}$. The prepared AuNRs were washed two times with water and centrifugated $(3100 \times g)$ at $15^{\circ} \mathrm{C}$ for $10 \mathrm{~min}$. Finally, the pellet was resuspended in water. The prepared AuNRs were stored at $4^{\circ} \mathrm{C}$ in the dark.

Modification of AuNPs using salt-aging method. For salt-aging method ${ }^{17}$, $400 \mu \mathrm{L}$ of AuNPs solution was mixed with $20 \mu \mathrm{L}$ of $100 \mu \mathrm{M}$ poly $(\mathrm{A} / \mathrm{T} / \mathrm{C} / \mathrm{G})$-tagged DNA probes and incubated for $24 \mathrm{~h}$. Then, $40 \mu \mathrm{L}$ of $125 \mathrm{mM}$ sodium phosphate buffer ( $\mathrm{pH} 7.4)$ and $40 \mu \mathrm{L}$ of $1.25 \mathrm{M} \mathrm{NaCl}$ was gradually added into the mixture. After incubating for $40 \mathrm{~h}$, the particles were washed three times with $0.01 \mathrm{M}$ phosphate buffer $(0.1 \mathrm{M} \mathrm{NaCl}, \mathrm{pH} 7.4)$ through centrifugation $(12,400 \times g)$ at $4{ }^{\circ} \mathrm{C}$ for 20 min to remove excess DNA strands. Finally, the resulted conjugates were resuspended in buffers with different concentration of $\mathrm{NaCl}$.

Modification of AuNPs using low-pH method. For low-pH method ${ }^{21}, 400 \mu \mathrm{L}$ of AuNPs solution was mixed with $20 \mu \mathrm{L}$ of $100 \mu \mathrm{M}$ poly (A/T/C/G)-tagged DNA probes. Then, $8 \mu \mathrm{L}$ of $500 \mathrm{mM}$ citrate buffer $(\mathrm{pH} 3)$ was added to lower the $\mathrm{pH}$ of the solution. After brief vortex mixing, the mixture was incubated at room temperature for $3 \mathrm{~min}$. Next, $12 \mu \mathrm{L}$ of $1 \mathrm{M}$ HEPES buffer ( $\mathrm{pH} 7.6$ ) was added to the mixture to adjust the $\mathrm{pH}$ back to a neutral state. Subsequently, the particles were washed three times with $0.01 \mathrm{M}$ phosphate buffer $(0.1 \mathrm{M} \mathrm{NaCl}, \mathrm{pH} 7.4)$ through centrifugation $(12,400 \times g)$ at $4{ }^{\circ} \mathrm{C}$ for $20 \mathrm{~min}$. Finally, the resulted conjugates were resuspended in buffers with different concentrations of $\mathrm{NaCl}$.

Modification of AuNPs using freeze-thaw method. For freeze-thaw method 26,29 $400 \mu \mathrm{L}$ of AuNPs solution was mixed with $20 \mu \mathrm{L}$ of $100 \mu \mathrm{M}$ poly $(\mathrm{A} / \mathrm{T} / \mathrm{C} / \mathrm{G})$-tagged DNA probes. The above mixture was frozen at $-20^{\circ} \mathrm{C}$ for $1 \mathrm{~h}$ and then thawed at room temperature. After that, the particles were washed three times with $0.01 \mathrm{M}$ phosphate buffer $(0.1 \mathrm{M} \mathrm{NaCl}, \mathrm{pH} 7.4)$ through centrifugation $(12,400 \times g)$ at $4{ }^{\circ} \mathrm{C}$ for $20 \mathrm{~min}$. Finally, the resulted conjugates were resuspended in buffers with different concentrations of $\mathrm{NaCl}$.

Modification of AuNPs using butanol extraction method. For butanol extraction method $^{25}, 100 \mu \mathrm{L}$ of AuNPs solution was mixed with $5 \mu \mathrm{L}$ of $100 \mu \mathrm{M}$ poly (A/T/C/ $\mathrm{G})$-tagged DNA probes. And then, $900 \mu \mathrm{L}$ of n-butanol was added to the mixture, followed by a quick vortex mixing. Subsequently, $200 \mu \mathrm{L}$ of $0.5 \times \mathrm{TBE}$

(44.5 mM Tris, $1 \mathrm{mM}$ EDTA, $44.5 \mathrm{mM}$ boric acid, $\mathrm{pH}$ 8.0) buffer was added to the above solution followed by quick vortex mixing. The mixture was centrifugated at $2000 \times g$ for several seconds to facilitate a liquid phase separation. The liquid phase with particles was pipetted and washed three times with $0.01 \mathrm{M}$ phosphate buffer $(0.1 \mathrm{M} \mathrm{NaCl}, \mathrm{pH} 7.4)$ through centrifugation $(12,400 \times g)$ at $4{ }^{\circ} \mathrm{C}$ for $20 \mathrm{~min}$. Finally, the particles were resuspended in buffers with different concentrations of $\mathrm{NaCl}$.

\section{Modification of AuNPs with DNA/RNA using MW-assisted heating-dry}

method. In total, $400 \mu \mathrm{L}$ of AuNPs solution was mixed with $20 \mu \mathrm{L}$ of $100 \mu \mathrm{M}$ SH DNA or poly (T)-DNA or poly (U)-RNA probes in $5 \mathrm{~mL}$ glass bottle. Then, put the glass bottle into a domestic microwave oven (the microwave input power is $1150 \mathrm{~W}$ and the microwave output power is $700 \mathrm{~W}$ ) and heated at middle-high model for $3 \mathrm{~min}$, followed by resuspension with $\mathrm{ddH}_{2} \mathrm{O}$ or $0.01 \mathrm{M}$ phosphate buffer $(0.1 \mathrm{M}$ $\mathrm{NaCl}, \mathrm{pH} 7.4)$. After that, the particles were washed with $0.01 \mathrm{M}$ phosphate buffer $(0.3 \mathrm{M} \mathrm{NaCl}, \mathrm{pH} 7.4)$ and centrifugated $(12,400 \times g)$ at $15^{\circ} \mathrm{C}$ for $20 \mathrm{~min}$. Finally, the pellet was resuspended in buffers with different $\mathrm{NaCl}$ concentrations, and the resulted nucleic acid-AuNP conjugates were stored at $4{ }^{\circ} \mathrm{C}$ in the dark or used for subsequent experiment. 
Fluorescence quantification of the surface density of DNA-AuNP conjugates. Poly (T)-tagged DNA used in these studies were labeled with FAM at 3 '-terminal (Supplementary Table 2). FAM-labeled DNA were first absorbed to AuNPs surface following the protocol as above described. The FAM-DNA-AuNP conjugates were resuspended in $0.01 \mathrm{M}$ phosphate buffer $(0.3 \mathrm{M} \mathrm{NaCl}, \mathrm{pH}$ 7.4) or $10 \mathrm{mM}$ HEPES buffer. The surface density of the DNA-AuNP conjugate was quantitated according to the published protocol ${ }^{56}$. First, $\beta$-mercaptoethanol (ME, catalog number: 63689) was added ( $20 \mathrm{mM}$ final concentration) to the FAM-labeled DNA-AuNPs solution and incubated overnight with shaking at room temperature. Then, the mixture was centrifugated at $15^{\circ} \mathrm{C}$ at $12,400 \times g$ for $20 \mathrm{~min}$ and the supernatant was collected. The released FAM-DNA probes were in the supernatant and the fluorescence was measured by SpectraMax iD5 Multimode Microplate Reader (Molecular Devices, CA, USA). The fluorescence intensity was converted to the molar concentration of DNA probes by interpolation from a standard linear calibration curve that was prepared with known concentrations of same FAM-DNA probes at same buffer condition and ME concentration. AuNPs concentration was determined via the absorption of UV-vis spectra and finally the number of DNA on each AuNP could be calculated.

Surface-enhanced Raman spectroscopy (SERS) analysis. The DNA-AuNP conjugates were obtained using MW-based heating-drying method as above described and resuspended in $0.01 \mathrm{M}$ phosphate buffer $(0.3 \mathrm{M} \mathrm{NaCl}, \mathrm{pH}$ 7.4). $10 \mu \mathrm{L}$ of $10 \mu \mathrm{M}$ ROX-labeled DNA probes complementary to DNA-AuNP conjugates were firstly added to $200 \mu \mathrm{L}$ DNA-AuNP solution. After $2 \mathrm{~h}$ incubation at $37^{\circ} \mathrm{C}$ for efficient hybridization, the particles were washed three time with $0.01 \mathrm{M}$ phosphate buffer $(0.3 \mathrm{M} \mathrm{NaCl}, \mathrm{pH} 7.4)$ and centrifugated at $15^{\circ} \mathrm{C}$ at $12,400 \times g$ for $20 \mathrm{~min}$. Then the supernatant was discarded and the pellet $(20 \mu \mathrm{L})$ was collected for SERS measurements. For SERS analysis, the $20 \mu \mathrm{L}$ pellet was dropped on the Si substrate and the SERS measurement was performed using Renishaw inVia microspectrometer (Derbyshire, England). A He-Ne laser operating at $\lambda=633 \mathrm{~nm}$ was used as the excitation source with a laser power of approximately $10 \mathrm{~mW}$. All the Raman spectra reported in this work were collected for exposure times of $10 \mathrm{~s}$ in the range from 1000 to $1800 \mathrm{~cm}^{-1}$.

\section{Circular dichroism measurements. The G4-DNA-AuNP conjugates were} obtained using MW-based heating-drying method as above described. The G4DNA was diluted in $50 \mathrm{mM}$ Tris- $\mathrm{HCl}(100 \mathrm{mM} \mathrm{KCl}, \mathrm{pH}$ 8.5). The G4-DNA-AuNP conjugates were washed two times with $50 \mathrm{mM}$ Tris- $\mathrm{HCl}(100 \mathrm{mM} \mathrm{KCl}, \mathrm{pH} 8.5)$ and centrifugated at $15^{\circ} \mathrm{C}$ at $12,400 \times g$ for $20 \mathrm{~min}$, followed by resuspending in $50 \mathrm{mM}$ Tris- $\mathrm{HCl}(100 \mathrm{mM} \mathrm{KCl}, \mathrm{pH} 8.5)$. The CD spectra of G4-DNA and G4DNA-AuNP conjugates were collected by a JASCOJ-810 spectropolarimeter (Tokyo, Japan), of which the lamp was always kept under dry purified nitrogen condition during measurements. Three times of scanning from 220 to $310 \mathrm{~nm}$ with the scan rate of $100 \mathrm{~nm} \mathrm{~min}^{-1}$ was performed and averaged. The background signal of the $50 \mathrm{mM}$ Tris- $\mathrm{HCl}(100 \mathrm{mM} \mathrm{KCl}, \mathrm{pH}$ 8.5) buffer was subtracted from the CD data.

Synthesis of sgRNA. sgRNA and poly (U)-tagged sgRNA have been transcribed in vitro. The DNA template with or without poly (T) sequence was obtained as previous report by a fill-in PCR method ${ }^{57} .500 \mu \mathrm{L}$ transcription reactions were performed with $0.5 \mathrm{mM}$ NTPs, $250 \mathrm{U}$ T7 RNA polymerase (catalog number: M0251L), 50 U recombinant RNase inhibitor (RRI, catalog number: 2313A), and 500 ng DNA template. The mixture was incubated for $12 \mathrm{~h}$ at $37^{\circ} \mathrm{C}$. Then, DNase I (catalog number: M0303S) was added to digest the DNA template and the RNA transcripts were purified by RNA Clean \& Concentrator Kits. The concentration of RNA products was determined by Nanodrop 2000.

Synthesis of long RNA of $\boldsymbol{N}$ gene of SARS-CoV-2. Poly (U)-tagged long RNA (1278 bp) of $N$ gene of SARS-CoV-2 has been transcribed in vitro. The DNA template with or without poly (T) sequence was obtained by a RT-PCR of SARSCoV-2 RNA standards. The primers were designed according to the sequence of $N$ gene (Supplementary Table 3). The RT-PCR thermal cycling program: reverser transcription at $50^{\circ} \mathrm{C}$ for $45 \mathrm{~min}$, pre-denaturation of cDNA at $94^{\circ} \mathrm{C}$ for $2 \mathrm{~min}$, followed by 40 cycles of amplification at $94^{\circ} \mathrm{C}$ for $30 \mathrm{~s}, 55^{\circ} \mathrm{C}$ for $30 \mathrm{~s}, 72^{\circ} \mathrm{C}$ for $2 \mathrm{~min}$, finally incubated at $72{ }^{\circ} \mathrm{C}$ for $10 \mathrm{~min}$. The PCR products containing T7 promoter was verified by gel electrophoresis and the template was collected using gel extraction kit. The purified DNA templates were then used for in vitro transcription system as above described. RNA transcripts were purified and concentrated by RNA Clean \& Concentrator Kits (catalog number: R1017) and the resulted RNA concentration was determined by Nanodrop 2000.

Preparation of the test strip device. The test trip device consists of sample pad, conjugate pad, nitrocellulose (NC) filter membrane, test line, control line, absorbent pad, and adhesive pad. The sample pad was firstly immersed into a $50 \mathrm{mM}$ Tris-HCl buffer $(0.15 \mathrm{M} \mathrm{NaCl}, 0.25 \%$ Triton X-100, $\mathrm{pH} 8.0)$ and then dried at $37^{\circ} \mathrm{C}$ for $2 \mathrm{~h}$. Streptavidin was embedded in the test line and streptavidin-biotinylated DNA probes was embedded in the control line. The intervals between two adjacent lines were $6 \mathrm{~mm}$. Then the NC membrane was dried at $37^{\circ} \mathrm{C}$ for $1 \mathrm{~h}$. Subsequently, the sample pad, conjugate pad, and absorbent pad were attached to the adhesive pad with $2 \mathrm{~mm}$ overlap. Finally, the prepared test strip was cut with a width of $4 \mathrm{~mm}$ and stored at $4{ }^{\circ} \mathrm{C}$.

Test strip assay to evaluate the hybridization efficiency of DNA-AuNP conjugates. The DNA-AuNP conjugates were obtained using MW-assisted heating-dry method. The $200 \mu \mathrm{L}$ DNA-AuNP solution was washed twice with $0.01 \mathrm{M}$ phosphate buffer $(0.1 \mathrm{M} \mathrm{NaCl}, \mathrm{pH} 7.4)$ by centrifugation at $15^{\circ} \mathrm{C}$ at $12,400 \times g$ for $20 \mathrm{~min}$. Subsequently, the pellet was resuspended in $200 \mu \mathrm{L}$ resuspension buffer $(20 \mathrm{mM}$ $\mathrm{Na}_{3} \mathrm{PO}_{4}, 5 \% \mathrm{BSA}, 0.25 \%$ Tween-20, and $10 \%$ sucrose). In all, $10 \mu \mathrm{L}$ resuspended DNA-AuNP conjugates were mixed with $10 \mu \mathrm{L}$ running buffer $(4 \times$ SSC, $0.05 \%$ Tween-20 $(v / v), 1 \times$ PBS, and $1 \%$ BSA), and then the above mixture was added to the sample pad of the test trip device. Finally, $100 \mu \mathrm{L}$ running buffer was added on the sample pad to wash the test strip, and the test strip was photographed after $5 \mathrm{~min}$.

Padlock-based ligation and RCA reaction. Ligation of the linear padlock probe was performed in a $10 \mu \mathrm{L}$ reaction solution containing $10 \mathrm{mM}$ Tris- $\mathrm{HCl}$ buffer $(50 \mathrm{mM} \mathrm{KCl}, 1.5 \mathrm{mM} \mathrm{MgCl}, \mathrm{pH} 8.9), 500 \mathrm{nM}$ padlock probe, $500 \mathrm{nM}$ matched target DNA, $10 \mathrm{U}$ T4 ligase. The above solution was incubated at $37^{\circ} \mathrm{C}$ for $30 \mathrm{~min}$ Subsequently, a total of $20 \mu \mathrm{L}$ RCA reaction system containing $10 \mathrm{mM}$ Tris- $\mathrm{HCl}$ buffer (50 mM KCl, $1.5 \mathrm{mM} \mathrm{MgCl}_{2}, \mathrm{pH} 8.9$ ), $1.25 \mathrm{mM}$ dNTP mix, $3.2 \mathrm{U}$ Bst 2.0 WarmStart DNA polymerase, and $10 \mu \mathrm{L}$ ligation products, was perform at $60^{\circ} \mathrm{C}$ for $60 \mathrm{~min}$. The RCA products were analyzed by gel electrophoresis.

\section{Loading of AuNPs with RCA products using MW-assisted heating-dry} method. $400 \mu \mathrm{L}$ of AuNPs solution was mixed with $20 \mu \mathrm{L}$ RCA products in $5 \mathrm{~mL}$ glass bottle. Then, put the glass bottle into a microwave oven and heated at middlehigh model for $3 \mathrm{~min}$, followed by resuspension with $\mathrm{ddH}_{2} \mathrm{O}$. After that, the solution was washed with $2 \mathrm{mM}$ Tris- $\mathrm{HCl}$ buffer $(10 \mathrm{mM} \mathrm{KCl}, 0.3 \mathrm{mM} \mathrm{MgCl}, \mathrm{pH}$ 8.9) and then washed with water by centrifugation at $15^{\circ} \mathrm{C}$ at $12,400 \times g$ for $20 \mathrm{~min}$. Finally, the pellet was resuspended in $1 \mathrm{M} \mathrm{NaCl}$ solution.

Modification of AuNPs with poly (U)-tagged sgRNA and poly (U)-tagged long RNA of $\boldsymbol{N}$ gene (1278 bp) of SARS-CoV-2. In all, $400 \mu \mathrm{L}$ of AuNPs solution was mixed with $10 \mu \mathrm{L}$ of $50 \mu \mathrm{M}$ poly (U)-tagged sgRNA or $320 \mu \mathrm{g}$ poly (U)-tagged long RNA in $5 \mathrm{~mL}$ glass bottle. Then, put the glass bottle into microwave oven and heated at middle-high model for $3 \mathrm{~min}$, followed by resuspension with $\mathrm{dd}_{2} \mathrm{O}$. After that, the solution was firstly washed with $0.02 \mathrm{M}$ phosphate buffer $(0.3 \mathrm{M}$ $\mathrm{NaCl}, \mathrm{pH} 7.4)$ and then washed with water by centrifugation at $15^{\circ} \mathrm{C}$ at $12,400 \times g$ for $20 \mathrm{~min}$. Finally, the pellet was resuspended in $1 \mathrm{M} \mathrm{NaCl}$ solution.

Test strip assay for nucleic acid detection based on Cas9/sgRNA-AuNP conjugates. In all, $200 \mu \mathrm{L}$ sgRNA-AuNP conjugates were firstly washed with $\mathrm{ddH}_{2} \mathrm{O}$ for 2 times by centrifugation at $15^{\circ} \mathrm{C}$ at $12,400 \times g$ for $20 \mathrm{~min}$ and the pellet was resuspended in $10 \mathrm{mM}$ Tris-HCl buffer ( $50 \mathrm{mM} \mathrm{KCl}, 1.5 \mathrm{mM} \mathrm{MgCl}_{2}, \mathrm{pH} 8.9$ ). The test strip assay was performed in $20 \mu \mathrm{L}$ reaction solution included $200 \mathrm{nM}$ Cas9 protein, $15 \mu \mathrm{L}$ sgRNA-AuNP conjugates, $0.5 \mu \mathrm{L}$ of $100 \mathrm{mM}$ Tris- $\mathrm{HCl}$ buffer (500 mM KCl, $15 \mathrm{mM} \mathrm{MgCl}_{2}, \mathrm{pH} 8.9$ ) and $2 \mu \mathrm{L}$ PCR products. The mixture was incubated at $37^{\circ} \mathrm{C}$ for $30 \mathrm{~min}$. Then, the above solution was added to the sample pad of the test strip device. Subsequently, $50 \mu \mathrm{L}$ running buffer $(4 \times$ SSC, $0.05 \%$ Tween-20 $(v / v), 1 \times$ PBS, and 1\% BSA) was added on the sample pad. After 2 min, photographed the lateral flow device.

Amplification of B646L (VP72) gene of ASFV by PCR. The PCR reaction of the B646L (VP72) gene was performed using a Premix Ex Taq ${ }^{\mathrm{mm}}$ II. PCR primers were designed according to the B646L (VP72) conserved region of African swine fever virus (ASFV) (Supplementary Table 3). A total of $40 \mu \mathrm{L}$ amplification system contained $500 \mathrm{nM}$ forward and reverse primer, the genome samples and $1 \times$ PCR reagent. The PCR thermal cycling program was: $95^{\circ} \mathrm{C}$ for $30 \mathrm{~s}$, followed by 40 cycles of amplification at $95^{\circ} \mathrm{C}$ for $5 \mathrm{~s}, 59^{\circ} \mathrm{C}$ for $30 \mathrm{~s}$, a final extension at $72{ }^{\circ} \mathrm{C}$ for $10 \mathrm{~min}$ and a $10^{\circ} \mathrm{C}$ hold. The PCR products were analyzed by gel electrophoresis

\section{Data availability}

The authors declare that the data supporting the findings of this study are available within the paper and its Supplementary Information files. Raw datasets generated during the study are available for research purposes from the corresponding authors on reasonable request. Source data are provided with this paper.

Received: 7 March 2021; Accepted: 25 January 2022; Published online: 18 February 2022

\section{References}

1. Saha, K., Agasti, S. S., Kim, C., Li, X. N. \& Rotello, V. M. Gold nanoparticles in chemical and biological sensing. Chem. Rev. 112, 2739-2779 (2012). 
2. Jans, H. \& Huo, Q. Gold nanoparticle-enabled biological and chemical detection and analysis. Chem. Soc. Rev. 41, 2849-2866 (2012).

3. Lee, J. S. et al. Gold, poly ( $\beta$-amino ester) nanoparticles for small interfering RNA delivery. Nano Lett. 9, 2402-2406 (2009).

4. Macfarlane, R. J. et al. Nanoparticle superlattice engineering with DNA Science 334, 204-208 (2011).

5. Sperling, R. A., Gil, P. R., Zhang, F., Zanella, M. \& Parak, W. J. Biological applications of gold nanoparticles. Chem. Soc. Rev. 37, 1896-1908 (2008).

6. Cutler, J. I., Auyeung, E. \& Mirkin, C. A. Spherical nucleic acids. J. Am. Chem. Soc. 134, 1376-1391 (2012).

7. Giljohann, D. A., Seferos, D. S., Prigodich, A. E., Patel, P. C. \& Mirkin, C. A. Gene regulation with polyvalent siRNA-nanoparticle conjugates. J. Am. Chem. Soc. 131, 2072-2073 (2009).

8. Elghanian, R., Storhoff, J. J., Mucic, R. C., Letsinger, R. L. \& Mirkin, C. A. Selective colorimetric detection of polynucleotides based on the distance-dependent optical properties of gold nanoparticles. Science 277, 1078-1081 (1997).

9. Rosi, N. L. et al. Oligonucleotide-modified gold nanoparticles for intracellular gene regulation. Science 312, 1027-1030 (2006).

10. Seferos, D. S., Giljohann, D. A., Hill, H. D., Prigodich, A. E. \& Mirkin, C. A. Nano-flares: probes for transfection and mRNA detection in living cells. J. Am. Chem. Soc. 129, 15477-15479 (2007).

11. Wilson, R. The use of gold nanoparticles in diagnostics and detection. Chem. Soc. Rev. 37, 2028-2045 (2008).

12. Giljohann, D. A. et al. Gold nanoparticles for biology and medicine. Angew. Chem. Int. Ed. 49, 3280-3294 (2010)

13. Park, S. J., Taton, T. A. \& Mirkin, C. A. Array-based electrical detection of DNA with nanoparticle probes. Science 295, 1503-1506 (2002).

14. Li, J. X. et al. Application of DNA functionalized gold nanoparticles. Sci. Sin. Chim. 45, 1112-1144 (2015).

15. Zheng, J. et al. A spherical nucleic acid platform based on self-assembled DNA biopolymer for high-performance cancer therapy. ACS Nano 7, 6545-6554 (2013).

16. Kyriazi, M. et al. Multiplexed mRNA sensing and combinatorial-targeted drug delivery using DNA-gold nanoparticle dimers. ACS Nano 12, 3333-3340 (2018).

17. Mirkin, C. A., Letsinger, R. L., Mucic, R. C. \& Storhoff, J. J. A DNA-based method for rationally assembling nanoparticles into macroscopic materials. Nature 382, 607-609 (1996).

18. Pei, H. et al. Designed diblock oligonucleotide for the synthesis of spatially isolated and highly hybridizable functionalization of DNA-gold nanoparticle nanoconjugates. J. Am. Chem. Soc. 134, 11876-11879 (2012).

19. Liu, J. W. \& Lu, Y. Preparation of aptamer-linked gold nanoparticle purple aggregates for colorimetric sensing of analytes. Nat. Protoc. 1, 246-252 (2006).

20. Zhang, X., Liu, B. W., Dave, N., Servos, M. R. \& Liu, J. W. Instantaneous attachment of an ultrahigh density of nonthiolated DNA to gold nanoparticles and its applications. Langmuir 28, 17053-17060 (2012).

21. Zhang, X., Servos, M. R. \& Liu, J. W. Instantaneous and quantitative functionalization of gold nanoparticles with thiolated DNA using a $\mathrm{pH}$ assisted and surfactant-free route. J. Am. Chem. Soc. 134, 7266-7269 (2012).

22. $\mathrm{Zu}, \mathrm{Y}$. B. \& Gao, Z. Q. Facile and controllable loading of single-stranded DNA on gold nanoparticles. Anal. Chem. 81, 8523-8528 (2009).

23. $\mathrm{Xu}, \mathrm{Q}$. et al. Rapid, surfactant-free, and quantitative functionalization of gold nanoparticles with thiolated DNA under physiological $\mathrm{pH}$ and its application in molecular beacon-based biosensor. ACS Appl. Mater. Interfaces 8, 27298-27304 (2016).

24. Zhang, X., Servos, M. R. \& Liu, J. W. Ultrahigh nanoparticle stability against salt, $\mathrm{pH}$, and solvent with retained surface accessibility via depletion stabilization. J. Am. Chem. Soc. 134, 9910-9913 (2012).

25. Hao, Y., Li, Y. J., Song, L. \& Deng, Z. X. Flash synthesis of spherical nucleic acids with record DNA density. J. Am. Chem. Soc. 143, 3065-3069 (2021).

26. Liu, B. W. \& Liu, J. W. Freezing directed construction of bio/nano interfaces: reagentless conjugation, denser spherical nucleic acids, and better nanoflares. J. Am. Chem. Soc. 139, 9471-9474 (2017).

27. Paredes, E., Evans, M. \& Das, S. R. RNA labeling, conjugation and ligation. Methods 54, 251-259 (2011)

28. Wang, Y., Chen, Y. Y., Hu, Y. P. \& Fang, X. Y. Site-specific covalent labeling of large RNAs with nanoparticles empowered by expanded genetic alphabet transcription. Proc. Natl Acad. Sci. USA 117, 22823-22832 (2020).

29. Hu, M. L. et al. Single-step, salt-aging-free, and thiol-free freezing construction of AuNP-based bioprobes for advancing CRISPR-based diagnostics. J. Am. Chem. Soc. 142, 7506-7513 (2020).

30. Shin, M. D. et al. COVID-19 vaccine development and a potential nanomaterial path forward. Nat. Nanotechnol. 15, 646-655 (2020).

31. Mulligan, M. J. et al. Phase I/II study of COVID-19 RNA vaccine BNT162b1 in adults. Nature 586, 589-593 (2020).

32. Lee, B. et al. Nanoparticle delivery of CRISPR into the brain rescues a mouse model of fragile $\mathrm{X}$ syndrome from exaggerated repetitive behaviours. Nat. Biomed. Eng. 2, 497-507 (2018).
33. $\mathrm{Wu}, \mathrm{J}$. J. et al. Binding-mediated formation of ribonucleoprotein corona for efficient delivery and control of CRISPR/Cas9. Angew. Chem. Int. Ed. 60, 11104-11109 (2021)

34. Nelson, E. M. \& Rothberg, L. J. Kinetics and mechanism of single-stranded DNA adsorption onto citrate-stabilized gold nanoparticles in colloidal solution. Langmuir 27, 1770-1777 (2011).

35. Kappe, C. O. Controlled microwave heating in modern organic synthesis. Angew. Chem. Int. Ed. 43, 6250-6284 (2004).

36. Young, D. D., Nichols, J., Kelly, R. M. \& Deiters, A. Microwave activation of enzymatic catalysis. J. Am. Chem. Soc. 130, 10048-10049 (2008).

37. Opdahl, A., Petrovykh, D. Y., Kimura-Suda, H., Tarlov, M. J. \& Whitman, L. J. Independent control of grafting density and conformation of single-stranded DNA brushes. Proc. Natl Acad. Sci. USA 104, 9-14 (2007).

38. Demers, L. M. et al. Thermal desorption behavior and binding properties of DNA bases and nucleosides on gold. J. Am. Chem. Soc. 124, 11248-11249 (2002).

39. Demers, L. M. et al. A fluorescence-based method for determining the surface coverage and hybridization efficiency of thiol-capped oligonucleotides bound to gold thin films and nanoparticles. Anal. Chem. 72, 5535-5541 (2000)

40. Storhoff, J. J., Elghanian, R., Mirkin, C. A. \& Letsinger, R. L. Sequence-dependent stability of DNA-modified gold nanoparticles. Langmuir 18, 6666-6670 (2002).

41. Kimura-Suda, H., Petrovykh, D. Y., Tarlov, M. J. \& Whitman, L. J. Basedependent competitive adsorption of single-stranded DNA on gold. J. Am. Chem. Soc. 125, 9014-9015 (2003).

42. Brown, K. A., Park, S. J. \& Hamad-Schifferli, K. Nucleotide-surface interactions in DNA-modified Au-nanoparticle conjugates: sequence effects on reactivity and hybridization. J. Phys. Chem. C 112, 7517-7521 (2008).

43. Epanchintseva, A., Vorobjev, P., Pyshnyi, D. \& Pyshnaya, I. Fast and strong adsorption of native oligonucleotides on citrate-coated gold nanoparticles. Langmuir 34, 164-172 (2018).

44. Liu, B. W., Zhao, Y., Jia, Y. \& Liu, J. W. Heating drives DNA to hydrophobic regions while freezing drives DNA to hydrophilic regions of graphene oxide for highly robust biosensors. J. Am. Chem. Soc. 142, 14702-14709 (2020).

45. Zhang, X., Liu, B. W., Servos, M. R. \& Liu, J. W. Polarity control for nonthiolated DNA adsorption onto gold nanoparticles. Langmuir 29, 6091-6098 (2013)

46. Nilsson, M. et al. Padlock probes: circularizing oligonucleotides for localized DNA detection. Science 265, 2085-2088 (1994).

47. Ohno, H., Akamine, S. \& Saito, H. RNA nanostructures and scaffolds for biotechnology applications. Curr. Opin. Biotechnol. 58, 53-61 (2019).

48. Jasinski, D., Haque, F., Binzel, D. W. \& Guo, P. X. Advancement of the emerging field of RNA nanotechnology. ACS Nano 11, 1142-1164 (2017).

49. Sharifi, M. et al. Plasmonic gold nanoparticles: optical manipulation, imaging, drug delivery and therapy. J. Control. Release 311, 170-189 (2019).

50. Wang, X. S. et al. Clustered regularly interspaced short palindromic repeats/ Cas9-mediated lateral flow nucleic acid assay. ACS Nano 14, 2497-2508 (2020).

51. Xiong, E. H. et al. Simultaneous dual-gene diagnosis of SARS-CoV-2 based on CRISPR/Cas9-mediated lateral flow assay. Angew. Chem. Int. Ed. 133, 5367-5375 (2021)

52. Turkevitch, J., Stevenson, P. C. \& Hillier, J. Nucleation and growth process in the synthesis of colloidal gold. Discuss. Faraday Soc. 11, 55-75 (1951).

53. Hill, H. D. \& Mirkin, C. A. The bio-barcode assay for the detection of protein and nucleic acid targets using DTT-induced ligand exchange. Nat. Protoc. 1, 324-336 (2006).

54. Frens, G. Controlled nucleation for the regulation of the particle size in monodisperse gold suspensions. Nat. Phys. Sci. 241, 20-22 (1973).

55. Jana, N. R., Gearheart, L. \& Murphy, C. J. Wet chemical synthesis of high aspect ratio cylindrical gold nanorods. J. Phys. Chem. B 105, 4065-4067 (2001).

56. Demers, L. M. et al. A fluorescence-based method for determining the surface coverage and hybridization efficiency of thiol-capped oligonucleotides bound to gold thin films and nanoparticles. Anal. Chem. 72, 5535-5541 (2000)

57. Liu, W. P., Yu, H. H., Zhou, X. M. \& Xing, D. In vitro evaluation of CRISPR/ Cas9 function by an electrochemiluminescent assay. Anal. Chem. 88 8369-8374 (2016)

\section{Acknowledgements}

This work was supported by the National Natural Science Foundation of China (91959128 and 21874049 to X.Z.; 21904042 to E.X.; 81772246 to D.Z.), Special Project of Science and Technology Development of Guangdong Province (2017B020207011 to D.Z.), Guangdong Basic and Applied Basic Research Foundation (2021A1515010262 to E.X.), Opening Project of State Key Laboratory of Chemo/Biosensing and Chemometrics of Hunan University (2019004 to E.X.), Open Funds of the State Key Laboratory of Electroanalytical Chemistry (SKLEAC202001 to X.Z.).

\section{Author contributions}

X.Z., E.X., and M.Q.H. conceived the study. X.Z. and E.X. designed and supervised the study. M.Q.H. and E.X. performed the experiments and contributed the data 
analysis and management. Y.W. and H.L. contributed to the molecular simulations. M.Q.H., E.X., M.L.H., T.T., H.Y., and X.Z. were involved in the data interpretation, discussed the results, and commented on the study. D.Z. provided financial support. X.Z., E.X., and M.Q.H. wrote the manuscript. All authors reviewed and approved the manuscript.

\section{Competing interests}

X.Z., E.X., and M.Q.H. are named inventors of patent application number 202110274160.5. The remaining authors declare no competing interests.

\section{Additional information}

Supplementary information The online version contains supplementary material available at https://doi.org/10.1038/s41467-022-28627-8.

Correspondence and requests for materials should be addressed to Erhu Xiong or Xiaoming Zhou.

Peer review information Nature Communications thanks the anonymous reviewers for their contribution to the peer review of this work.
Reprints and permission information is available at http://www.nature.com/reprints

Publisher's note Springer Nature remains neutral with regard to jurisdictional claims in published maps and institutional affiliations.

(c) Open Access This article is licensed under a Creative Commons Attribution 4.0 International License, which permits use, sharing, adaptation, distribution and reproduction in any medium or format, as long as you give appropriate credit to the original author(s) and the source, provide a link to the Creative Commons license, and indicate if changes were made. The images or other third party material in this article are included in the article's Creative Commons license, unless indicated otherwise in a credit line to the material. If material is not included in the article's Creative Commons license and your intended use is not permitted by statutory regulation or exceeds the permitted use, you will need to obtain permission directly from the copyright holder. To view a copy of this license, visit http://creativecommons.org/ licenses/by/4.0/.

(C) The Author(s) 2022 